\title{
The genus Trichorhina Budde-Lund in Brazil, with description of seven new species (Isopoda, Oniscidea, Platyarthridae)
}

\author{
Leila A. Souza ${ }^{1}$, Joafrâncio P. de Araújo ${ }^{2} \&$ Ivanklin S. Campos-Filho ${ }^{3}$
}

1. Laboratório de Carcinicultura, Instituto Superior de Ciências Biomédicas, Universidade Estadual do Ceará, Campus do Itaperi, Av. Paranjana, 1700, 60740-903, Fortaleza, Ceará, Brasil. (leilasouza5000@gmail.com.br)

2. Programa de Pós-Graduação em Ciências Biológicas (Zoologia), Departamento de Sistemática e Ecologia, Centro de Ciências Exatas e da Natureza, Universidade Federal da Paraíba, 58059-900, João Pessoa, Paraíba, Brasil. (joafrancio@gmail.com)

3. Programa de Pós-Graduação em Biologia Animal, Departamento de Zoologia, Instituto de Biociências, Universidade Federal do Rio Grande do Sul, Av. Bento Gonçalves, 9500 , prédio 43435, 91501-970, Porto Alegre, Rio Grande do Sul, Brasil. (ivanklin.filho@gmail.com)

\begin{abstract}
Seven new species of Trichorhina Budde-Lund, 1908 are described, six from Southeastern Brazil, T. biumbonata sp. nov., T. lenkoi sp. nov., T. myrmecophila sp. nov., T. orensis sp. nov., T. sexdens sp. nov., T. tropidocerata sp. nov., and one from Central Brazil, T. crassisetae sp. nov. An emended diagnosis for the genus and a key to the 19 species recorded from Brazil are provided. Trichorhina acuta Araújo \& Buckup, 1994 is recorded to state of Mato Grosso do Sul.
\end{abstract}

KEYWORDS. Terrestrial isopods, taxonomy, South America, Neotropical Region.

RESUMO. O gênero Trichorhina Budde-Lund no Brasil, com descrição de sete espécies novas (Isopoda, Oniscidea, Platyarthridae). Sete espécies novas de Trichorhina Budde-Lund, 1908 são descritas, seis do sudeste do Brasil, T. biumbonata sp. nov., T. lenkoi sp. nov., T. myrmecophila sp. nov., T. orensis sp. nov., T. sexdens sp. nov. e T. tropidocerata sp. nov., e uma do Centro-Oeste, T. crassisetae sp. nov. São fornecidos uma diagnose emendada para o gênero e chave para as 19 espécies registradas para o Brasil. É registrada a ocorrência de Trichorhina acuta Araújo \& Buckup, 1994 para o Mato Grosso do Sul.

PALAVRAS-CHAVE. Isópodes terrestres, taxonomia, América do Sul, Região Neotropical.

Platyarthridae includes seven genera and numerous nominal species. There are 12 species of Trichorhina Budde-Lund, 1908 recorded for Brazil (Schmalfuss, 2003; Araúuo \& Almerão, 2007).

LeISTIKOW \& WÄGELE (1999) included Trichorhina pearsei (Creaser, 1938) from Mexico as occurring in Brazil. Perhaps this was a misinterpretation of SouzAKURY (1993), because its eyes could be compared with those of the species described therein and to comments on its synonymy.

The number of ommatidia forming the eye is used here as a primary diagnostic feature. It appears that there is a general trend in eye reduction (making part of a regressive evolution also evident in the reduction of body pigmentation) in many species of Trichorhina, not necessarily related to environment but more generally to an endogeous lifestyle.

There are numerous specimens of anophtalmous Trichorhina not yet studied and deposited at Museu Nacional do Rio de Janeiro, along with many specimens collected in caves from the Brazilian states of Bahia, Minas Gerais, Paraná, and São Paulo that are temporarily being kept in Universidade Estadual do Ceará (UECE) for further investigation.

\section{MATERIAL AND METHODS}

Type specimens are deposited in the Museu Nacional, Universidade Federal do Rio de Janeiro (MNRJ), Rio de Janeiro, Brazil. The material examined of Trichorhina acuta is deposited in the collection of Oniscidea at Universidade Estadual do Ceará, Fortaleza, Brazil (UECE).
Five new species possess between four to six ommatidia and they may be compared to species which also possess a similar number of ommatidia. The other new taxa of Trichorhina, even though they possess between four and six ommatidia, could be considered unrelated with the new ones because of other unique features.

The structures to which we here refer as "rods" have been called by VANDEL (1952) "fins bâtonnets cilindriques". Graphics illustrating relative position of noduli laterales are used according to VANDEL (1962). Measurements refer to maximum values.

\section{Trichorhina Budde-Lund, 1908}

Type species: Bathytropa thermophila (Dollfus, 1896)

Diagnosis. Body length not exceeding $6 \mathrm{~mm}$. Pigmentation vestigial or absent. If there are eyes, they can be composed of up to 15 ommatidia. Tegument with fanshaped scale-setae. Exite of maxillula with simple, bifid or serrate teeth. Noduli laterales with or without lateral projections, 1 per side on pereonites I-VI and 1-2 per side on pereonite VII or as a double row per side. Frontal line absent (except in Trichorhina minutissima Budde-Lund, 1913, T. micros Budde-Lund, 1913 and T. atlasi Vandel, 1959). Without glandular pores [except in T. argentina Vandel, 1963 and T. boliviana (Vandel, 1952)]. Antennal flagellum bi-articulated; second joint much longer than first and sometimes with a suture. Telson triangular [except in T. simony (Dollfus, 1893), T. caeca Vandel, 1952 and T. tropicalis Lewis, 1998]. Without pleopodal lungs. Epigeous (including endogeous) and hipogeous (cave-dwellers), besides inhabitants of nests of ants and termites. 
Distribution. Trichorhina is cosmopolitan. There is a total of 56 species, of which about 30 occur in the Neotropical Region (Schmalfuss, 2003). There are 12 species hitherto recorded in Brazil, which added to the seven new species herein described, give a total of 64 species for the world (see Table I).

Remarks. Species of Trichorhina are mostly tropical. It is probably an artificial assemblage (e.g. TAITI \& FerRaRA, 1987). According to the current knowledge, there is a high degree of endemism for the majority of species but there are a few widespread species, such as T. tomentosa (Budde-Lund, 1893) and T. heterophthalma Lemos de Castro, 1964 which probably were dispersed by man.

Trichorhina albida Budde-Lund, 1908 from Madagascar. Possesses unique dorsal knobs ("dorsal buttons", Verhoeff, 1946) (although according to Dr. F. Ferrara pers. comm., in BudDE-Lund's (1908) original description no dorsal knobs are mentioned and Verhoeff has not reexamined the type specimens).

Trichorhina dobrogica Radu, 1960 from Romania. It may be distinguished from the Brazilian species by the transverse lines on pereonites I-VI, and a distal joint of antennula with nine aesthetascs (five or six in Brazilian species).

Trichorhina giannelli Arcangeli, 1929 from the Antilles and Central America. Distinguished from the new Brazilian species by the longitudinal ridges on the mesepistome.

Trichorhina guanophila Souza-Kury, 1993 from Brazil. This species belongs to the group of species characterized by a double pair of noduli laterales on pereonite VII.

Trichorhina micros from Mauritius and Trichorhina minutissima from Cargados (Indian Ocean). These taxa belong to the group of species characterized by serrate teeth on the outer ramus of the maxillulae and by a double row of noduli laterales per side (TAITI \& FERRARA, 1987).

Trichorhina minima Schmalfuss \& Ferrara, 1978 from Togo. It is distinguished from Brazilian species by the bulbous profrons.

Trichorhina quisquiliarum (Budde-Lund, 1893) from Venezuela. It is distinguished from new Brazilian species by the uneven pigmentation of ommatidia, four unpigmented and two dark colored.

Trichorhina tatianae Araújo \& Almerão, 2007 from Brazil. It is distinguished from the new Brazilian species by the pronounced lateral projection on male pereopod VII ischium.

Besides these nine species, there are ten others with four to six ommatidia, whose differences are cited separately under the diagnosis of each new species. These are: Trichorhina acuta from Brazil; T. argentina from Argentina; T. australiensis Wahrberg, 1922 from Australia; T. barbouri (van Name, 1926) from Panama; T. hospes Silvestri, 1918 from Nigeria; T. pallida
Barnard, 1960 from Mozambique; T. papillosa (BuddeLund, 1893) from Venezuela; T. paraensis Souza-Kury, 1997 from Brazil; T. silvestrii Arcangeli, 1936 from Spain; and T. vandeli Rioja, 1955 from Mexico.

\section{Trichorhina biumbonata sp. nov. (Figs 1, 8-24)}

Type material. Holotype $\widehat{\delta}$, BRAZIL, São Paulo: Descalvado, Escaramuça, 25.VI.1944, O. Schubart col. (MNRJ 21420). Paratypes: $3 \hat{\delta}, 3$, , same data as holotype (MNRJ 21421); $\hat{\partial}, 2$, , Descalvado, Diamantina, 27.VIII.1944, J. Schubart \& O. Schubart col. (MNRJ 11515).

Diagnosis. Pigmentation pale yellow. Eyes with five dark brown ommatidia. Second joint of antennal peduncle with a crest in the outer border. Second joint of antennal flagellum with a faint proximal groove.

Measurements. Male length: $2.75 \mathrm{~mm}$, width: $1.24 \mathrm{~mm}$; female length: $3.03 \mathrm{~mm}$, width: $1.51 \mathrm{~mm}$.

Description. Pigmentation of body faint, pale yellow, head with small brown spots. Eyes dark brown with five ommatidia (Fig. 10). Pereonite I with anterior margins reaching the eyes (Fig. 8). Cephalic lateral lobes small, shorter than median lobe which has rounded apex and straight sides (Fig. 9). Pleon slightly narrower than pereon. Pereon, pleon and telson densely provided with fan-shaped scale-setae (Fig. 15). In the posterior margins of pereonites these fan-shaped scale-setae are large and wide, alternating with small and narrow ones, and in the lateral margins they are small. Both median axes of fan-shaped scale-setae evident, as well as the secondary supporting axioles. Noduli laterales with featureless base. Pereonite VII with only one nodulus lateralis on each side. Position of noduli laterales as illustrated (Fig. 1). Antennula with distal joint with six to seven aesthetascs (Fig. 11). Second joint of antennal peduncle with longitudinal sinuous crest in outer border, more evident in the female (Fig. 12). Left mandible without rods between molar and incisory processes (Fig. 13). Six to seven penicils in molar process of mandibles (Figs 13, 14). Outer group of exite of maxillulae with three teeth and inner group with four undivided teeth (Fig. 16). Maxilla with inner lobe narrower than outer lobe. Sensilla on the inner lobe (Fig. 17). Endite of maxilliped with one small tooth in outer distal border, and with inner distal border smooth (Fig. 18). Pleopods without respiratory areas.

Male. Pereopods I (Fig. 19) and VII (Fig. 20) without apparent sexual dimorphism. Pleopod I with heart-shaped exopod (Fig. 21); endopod slender with half distal slightly turned to the outside and simple apex (Fig. 22). Pleopod II with triangular exopod (Fig. 24); endopod with distal half strongly tapered (Fig. 23). Pleopod V with exopod subtriangular.

Remarks. Trichorhina biumbonata sp. nov. is distinguished from the species with four to six ommatidia by the antennal crest, and further as follows: from T. acuta by maxillulae with undivided teeth (two 
Tab. I. Brazilian records of species of Trichorhina by microhabitats, regions and reference.

\begin{tabular}{|c|c|c|c|}
\hline Species & Microhabitat & Region & Reference \\
\hline T. acuta Araújo \& Buckup, 1994 & $\begin{array}{c}\text { Synanthropic, under dead } \\
\text { leaves, rotten fruit, bricks, } \\
\text { stones, wood, in garden. Under } \\
\text { log, on high tide line. }\end{array}$ & Southern & ARAújo \& BuCKuP, 1994 \\
\hline T. amazonica Souza-Kury, 1997 & Unknown & Northern & SouZA-KuRY, 1997 \\
\hline T. argentina Vandel, 1963 & $\begin{array}{l}\text { Synanthropic, under stones, } \\
\text { debris, wood and leaves. }\end{array}$ & Southern & ARAújo \& BuCKuP, 1996 \\
\hline T. bicolor Araújo \& Buckup, 1996 & $\begin{array}{l}\text { Synanthropic, under bricks, } \\
\text { among leaves of fruit trees. For- } \\
\text { est, in the leaf mold. }\end{array}$ & Southern & ARAúJo \& BuCKuP 1996 \\
\hline T. biumbonata sp. nov. & Unknown & Southeastern & This paper \\
\hline T. brasilensis (Andersson, 1960) & Under stones & Southern & $\begin{array}{l}\text { Andersson, 1960; SChUltz, 1995; } \\
\text { ARAúJo \& BuCKup, } 1996\end{array}$ \\
\hline T. crassisetae sp. nov. & In the leaf mold & Central & This paper \\
\hline T. guanophila Souza-Kury, 1993 & $\begin{array}{c}\text { In cave, in guano of vampire } \\
\text { bat }\end{array}$ & Northeastern & SOUZA-KuRY, 1993 \\
\hline T. heterophthalma Lemos de Castro, 1964 & $\begin{array}{l}\text { Beneath loose earth, among } \\
\text { roots }\end{array}$ & $\begin{array}{l}\text { Northeastern, } \\
\text { Southeastern }\end{array}$ & SouZA-KurY, 1993 \\
\hline T. lenkoi sp. nov. & In the leaf mold & Southeastern & This paper \\
\hline T. macrops Souza-Kury, 1993 & Unknown & Northeastern & SOUZA-KuRY, 1993 \\
\hline T. myrmecophila sp. nov. & In Camponotus nest & Southeastern & This paper \\
\hline T. orensis sp. nov. & In debris, on high tide line & Southeastern & This paper \\
\hline T. paraensis Souza-Kury, 1997 & Unknown & Northern & SouZA-KuRY, 1997 \\
\hline T. pittieri (Pearse, 1921) & $\begin{array}{l}\text { Sandy ground, covered with } \\
\text { dead leaves }\end{array}$ & Northern & Lemos de Castro, 1967 \\
\hline T. sexdens sp. nov. & Unknown & Southeastern & This paper \\
\hline T. tatianae Araújo \& Almerão, 2007 & In the leaf mold & Southern & ARAúJo \& Almerão, 2007 \\
\hline T. tomentosa (Budde-Lund, 1893) & $\begin{array}{l}\text { Beneath loose garden earth; in } \\
\text { rotten log; within ground bro- } \\
\text { meliad; among fern roots. }\end{array}$ & $\begin{array}{l}\text { Northern, } \\
\text { Southeastern, } \\
\text { Southern }\end{array}$ & $\begin{array}{c}\text { AraúJo \& BuckuP, 1996; SouZA-KurY, } \\
1997\end{array}$ \\
\hline T. tropidocerata sp. nov. & $\begin{array}{l}\text { Under bricks and stones, near } \\
\text { fishing station on the beach. }\end{array}$ & Southeastern & This paper \\
\hline
\end{tabular}

bifid in T. acuta). From T. argentina by the exopod of pleopod I of male cordiform (ovoid in $T$. argentina). From T. australiensis by 1) molar process of mandibles with six to seven penicils (one in T. australiensis); 2) seven undivided teeth in maxillulae (in T. australiensis nine, of which two bifid); 3) endite of maxilliped without tooth in inner distal border; with only one in outer distal border (one tooth in inner distal border; one in distal outer in T. australiensis). From T. barbouri by 1) second joint of antennal flagellum of female without groove; 2) tegument smooth. From T. hospes by maxillulae with seven undivided teeth (in T. hospes nine, two bifid). From T. pallida by 1) molar process of mandibles with five to seven penicils (two in T. pallida); 2) exite of maxillulae with seven undivided teeth (two of inner group bifid in T. pallida). From T. papillosa by 1) absence of papillae on tegument of body; 2) endopods of uropods surpass the tip of telson and of protopods. From T. paraensis by 1) antennula with distal joint with six to seven aesthetascs altogether (five altogether in two groups in T. paraensis); 2) molar process of both mandibles with six to seven penicils (one penicil in T. paraensis). From T. silvestrii by 1) antennula with distal joint with six to seven aesthetascs altogether (four in two groups in $T$. silvestrii); 2) molar process of both mandibles with six to seven penicils (three in T. silvestrii). From T. vandeli by 1) maxillulae with seven undivided teeth (in T. vandeli eight, two bifid); 2) endite of maxilliped with one tooth in outer distal border (two teeth in T. vandeli).

Etymology. From Latin $b i=$ two $+u m b o=$ protuberance, due to the sinuous protuberance forming a crest on the antennal peduncle. 

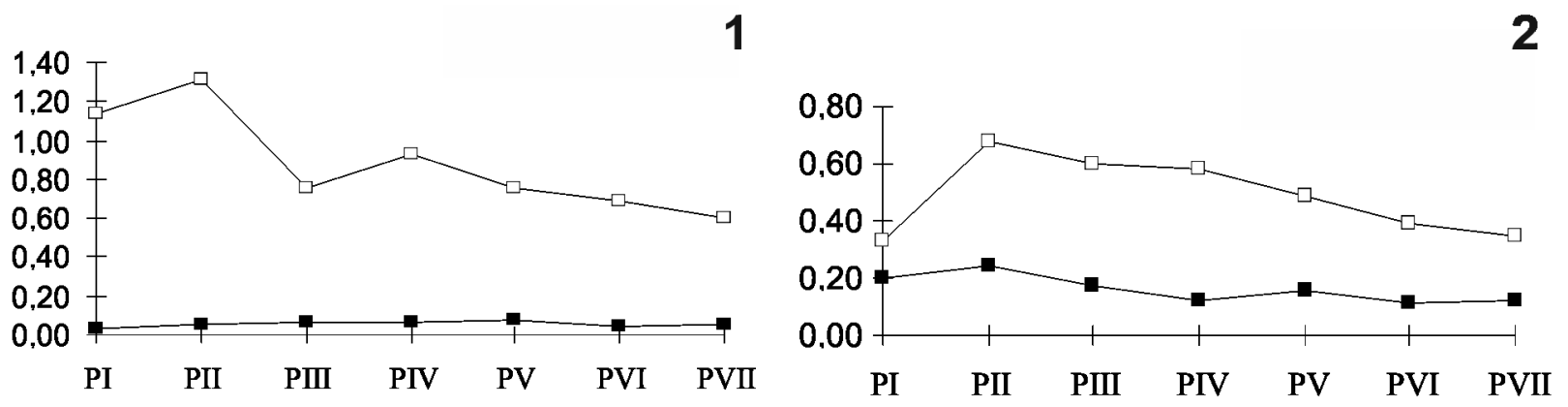

3

4
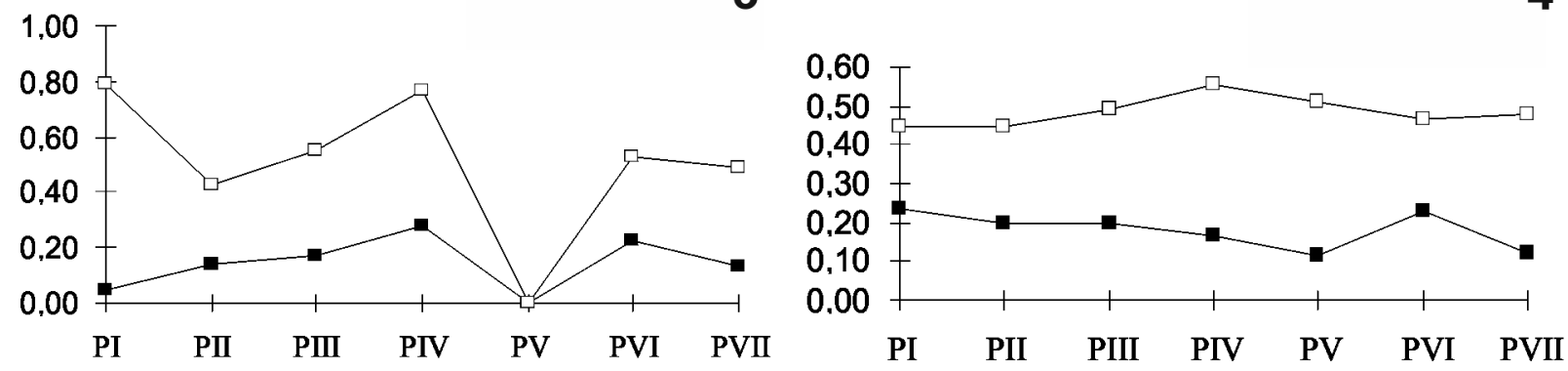

5
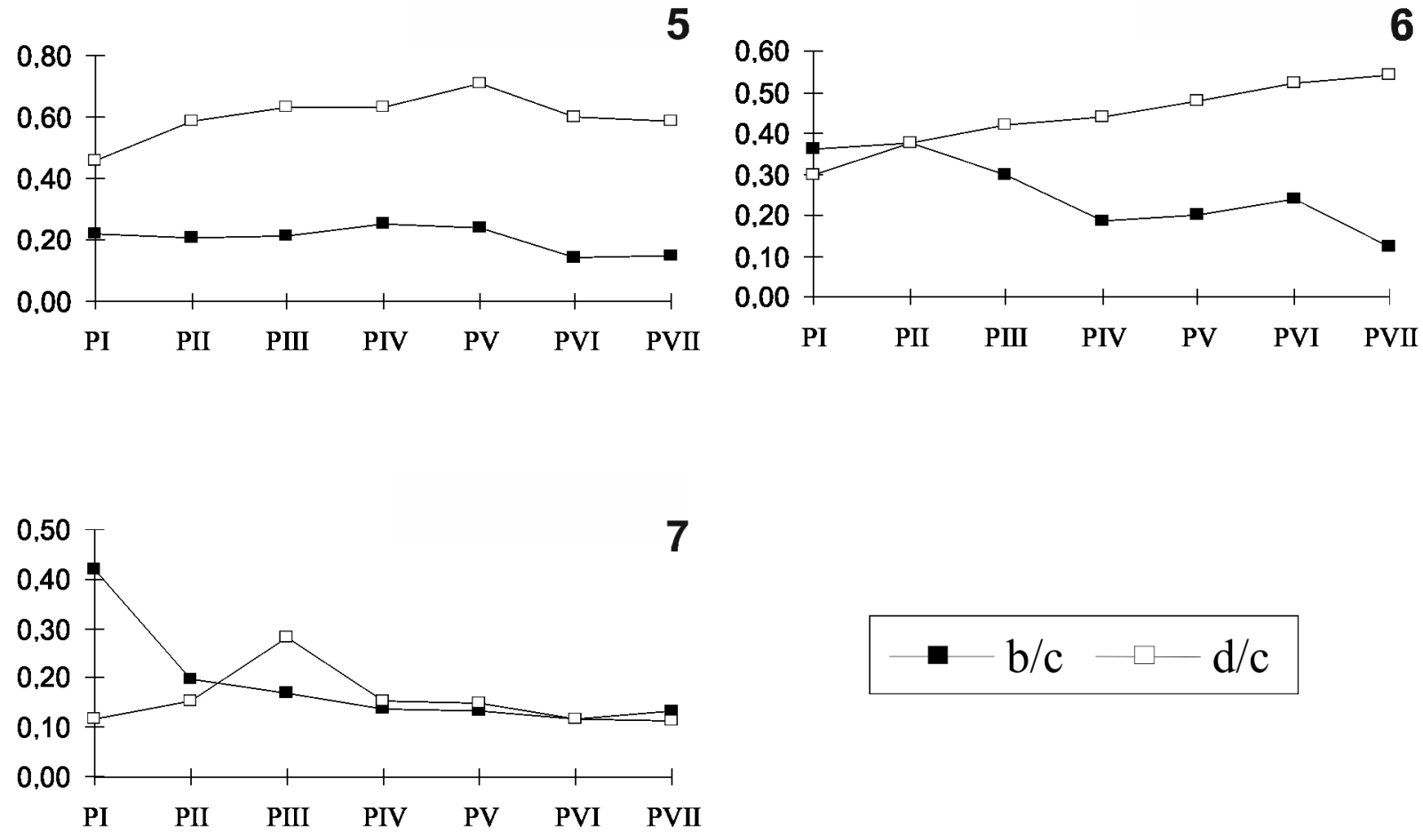

Figs 1-7. Ratio b/c and d/c of noduli laterales on pereonites I-VII: 1, Trichorhina biumbonata sp. nov.; 2, Trichorhina crassisetae sp. nov.; 3, Trichorhina lenkoi sp. nov.; 4, Trichorhina myrmecophila sp. nov.; 5, Trichorhina orensis sp. nov.; 6, Trichorhina sexdens sp. nov.; 7, Trichorhina tropidocerata sp. nov. 

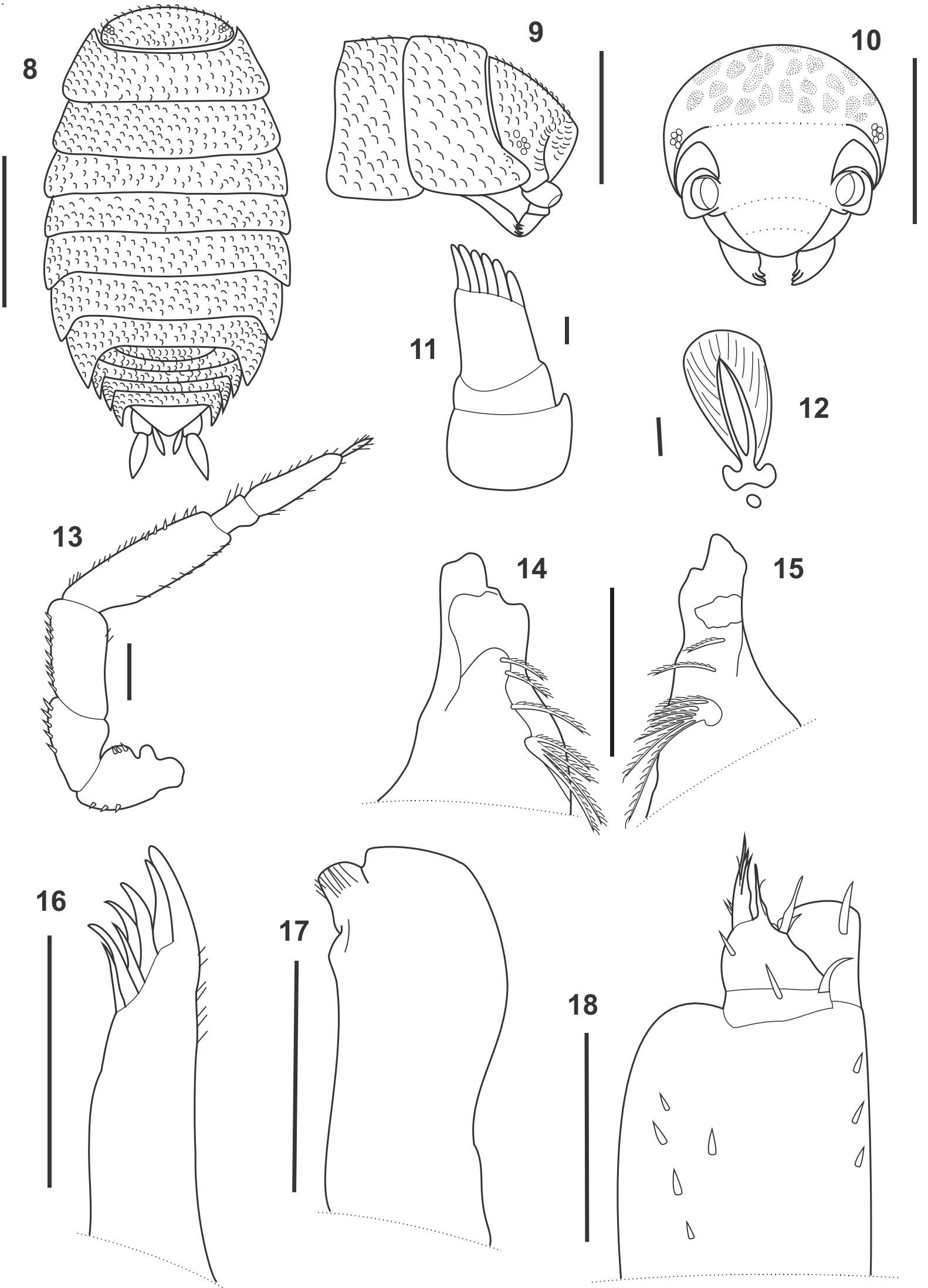

Figs. 8-18. Trichorhina biumbonata sp. nov. Female, habitus: 8, dorsal; 9, cephalothorax and two first pereonites, lateral view; 10, cephalothorax, frontal view. Male: 11, antennula; 12, antenna; 13, left mandible; 14, right mandible; 15, fan-shaped scale-seta of pereonite; 16, exite of maxillula; 17, maxilla; 18, maxilliped. Scale bars: fig. 8, $1 \mathrm{~mm}$; Figs 9-10, $0.5 \mathrm{~mm}$; Figs 11,15, $0.01 \mathrm{~mm}$; Figs 12, 13-14, 16-18, $0.1 \mathrm{~mm}$. 

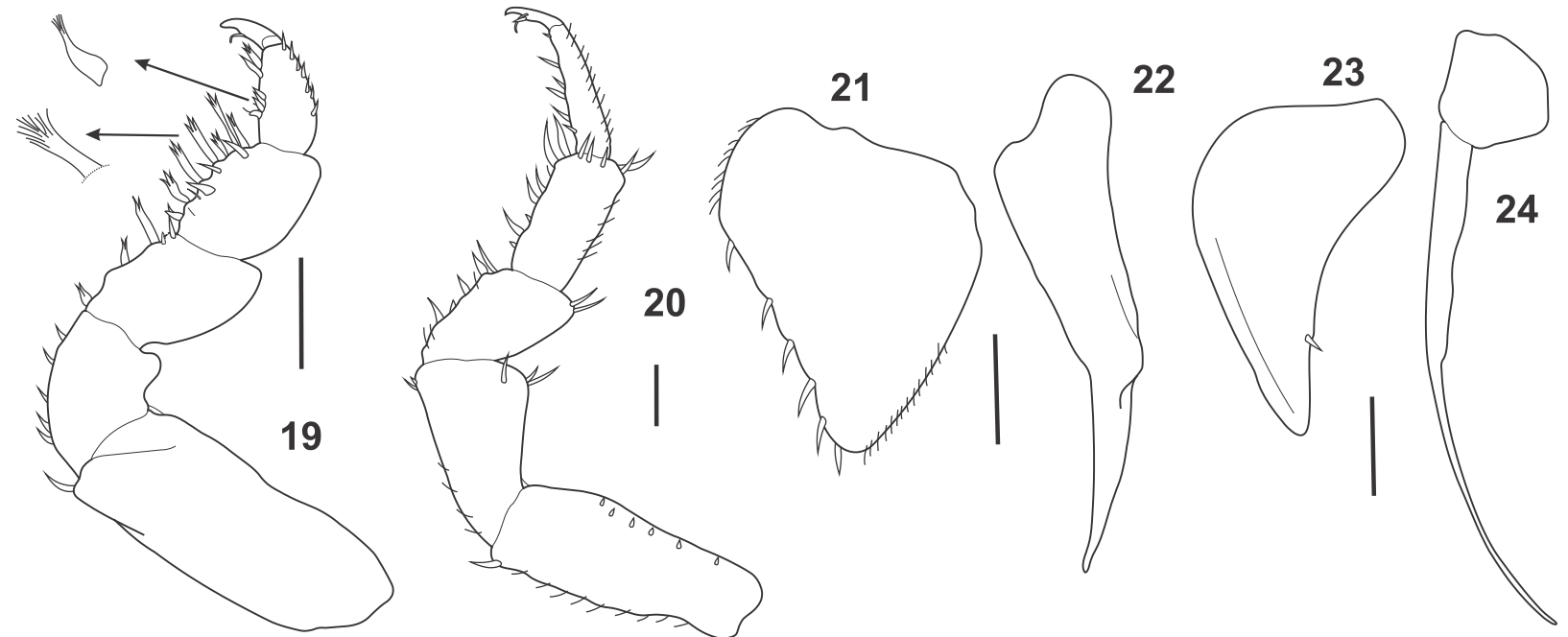

Figs. 19-24. Trichorhina biumbonata sp. nov. Male: 19, pereopod I; 20, pereopod VII; 21, exopod of pleopod I; 22, endopod of pleopod I; 23, exopod of pleopod II; 24, endopod of pleopod II. Scale bars: $0.1 \mathrm{~mm}$.

Trichorhina crassisetae sp. nov. (Figs 2; 25-43)

Type material. Holotype đิ, BRAZIL, Mato Grosso do Sul: Três Lagoas (Sucuriú river, Corredeira Chupão), in the forest along the river, in the leaf mold, VI.1964, without collector (MNRJ 4113). Paratypes: $8 \hat{0}, 8$, same data as holotype (MNRJ 4114).

Diagnosis. Pigmentation of body dark brown. Eyes with eight black ommatidia. Peduncle of antenna with conspicuous bristles. Exite of maxillulae with four teeth in the outer group, one very small. Pereopod I of male with setae bifurcated in carpus. Endopod of pleopod I of male with row of small setae in inner border.

Measurements. Male, length: $3.18 \mathrm{~mm}$, width: $1.19 \mathrm{~mm}$; female, length: $2.52 \mathrm{~mm}$, width: $1.06 \mathrm{~mm}$.

Description. Pigmentation of body dark brown; lighter in head (with small dark brown spots) (Fig. 25), antennae, sides of pereon and of pleon and uropods. Eyes black with eight ommatidia. Pereonite I with anterior margins reaching the eyes. Cephalic lateral lobes small, shorter than median lobe which has rounded apex and straight sides (Fig. 26). Eyes with eight ommatidia. Pleon outline continuous with pereon; pleonites III-V with well developed epimera. Pereon, pleon and telson covered with fan-shaped scale-setae (Fig. 27). In the posterior margins of pereonites, scalesetae large and wide intercalate with small and narrow, and in the lateral margins small. Fan-shaped scale-setae more or less rounded and with four shafted frame. Noduli laterales with featureless base. Pereonite VII with only one nodulus lateralis on each side. Position of noduli laterales as illustrated (Fig. 2). Distal joint of antennula with five aesthetascs (Fig. 28). Antenna (Fig. 29) stretched reaches posterior margin of pereonite II. Second joint of antennal peduncle without dorsal keel nor crest in outer border. Second joint of antennal flagellum without groove. Left mandible (Fig. 30) without rods between molar and incisory processes. Six penicils in molar process of left mandibles (Fig. 30), right four (Fig. 31). Outer group of exite of maxillulae with four teeth, one much smaller. Inner group of exite of maxillulae with four teeth: two bifid (Fig. 32). Maxilla with inner lobe narrower than outer lobe. Sensilla on the inner lobe (Fig. 33). Endite of maxilliped without small teeth in outer distal border, and with inner distal border smooth (Fig. 34). Pleopods without respiratory areas.

Male. Pereopod I (Fig. 35) with bifurcate setae in carpus, contrasting to that of female (Fig. 37); pereopod VII (Fig. 36) without prominent sexual dimorphism, compared to that of female (Fig. 38). Pleopod I with exopod subrectangular (Fig. 39); endopod with a row of small setae parallel to the inner border (Fig. 40). Pleopod II with triangular exopod (Fig. 41); endopod with distal half slender (Fig. 42). Pleopod V with exopod subrectangular (Fig. 43).

Remarks. Trichorhina crassisetae sp. nov. is distinguished from species with eight to twelve ommatidia as follows: from T. amazonica Souza-Kury, 1997 by 1) molar process of left mandible with six penicils (four in T. amazonica); 2) maxillulae with eight teeth, two bifid (in T. amazonica seven, two bifid). From $T$. atlasi by 1 ) absence of frontal line (frontal line very thin in T. atlasi); 2) sexual dimorphism in pereopod I of male: carpus with remarkable bifurcate setae (males without particular features, see VANDEL 1959:101, for T. atlasi); 3) pleonites three to five with well developed points (blunt in T. atlasi). From T. kribensis Ferrara \& Schmalfuss, 1983 by 1) antenna without aesthetascs; 2) exite of maxillulae with eight teeth, two bifid (nine undivided in T. kribensis); 3) pereopod VII of male without dimorphism. From T. marianii Arcangeli, 1930 by 1) tegument smooth (granulous in T. marianii); 2) sexual dimorphism in pereopod I of male: carpus with bifurcate setae (sexual dimorphism only in length and width of merus and carpus in $T$. marianii). From $T$. pubescens (Dollfus, 1893) by 1) antenna with joints 

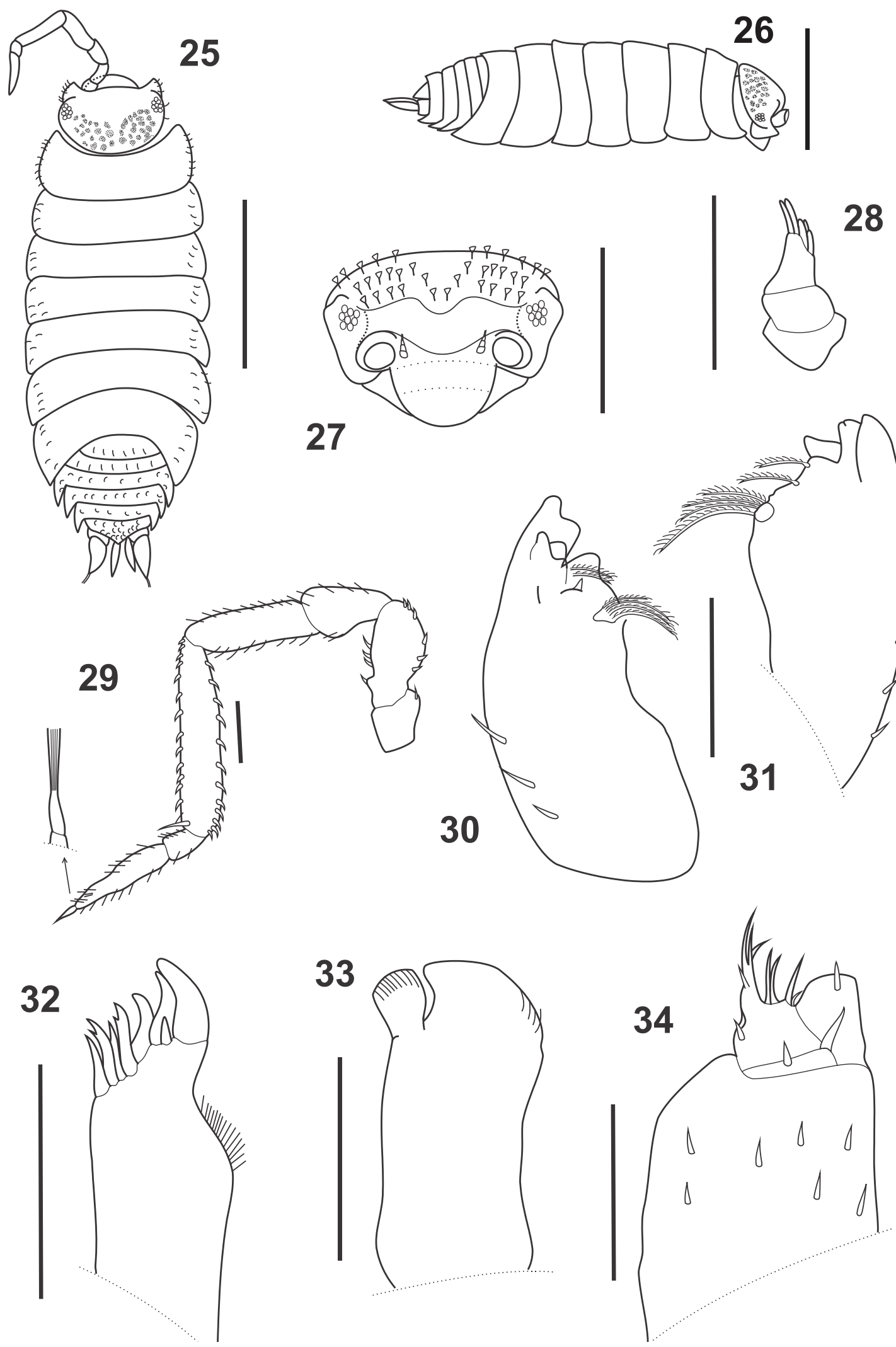

Figs. 25-34. Trichorhina crassisetae sp. nov. Female, habitus: 25, dorsal; 26, lateral; 27, cephalothorax, frontal view. Male: 28, antennula; 29, antenna; 30, left mandible; 31, right mandible; 32, exite of maxillula; 33, maxilla; 34, maxilliped. Scale bars: Figs 25-26, $1 \mathrm{~mm}$; Fig. 27, 0.5 mm; Figs $28-34,0.1 \mathrm{~mm}$. 


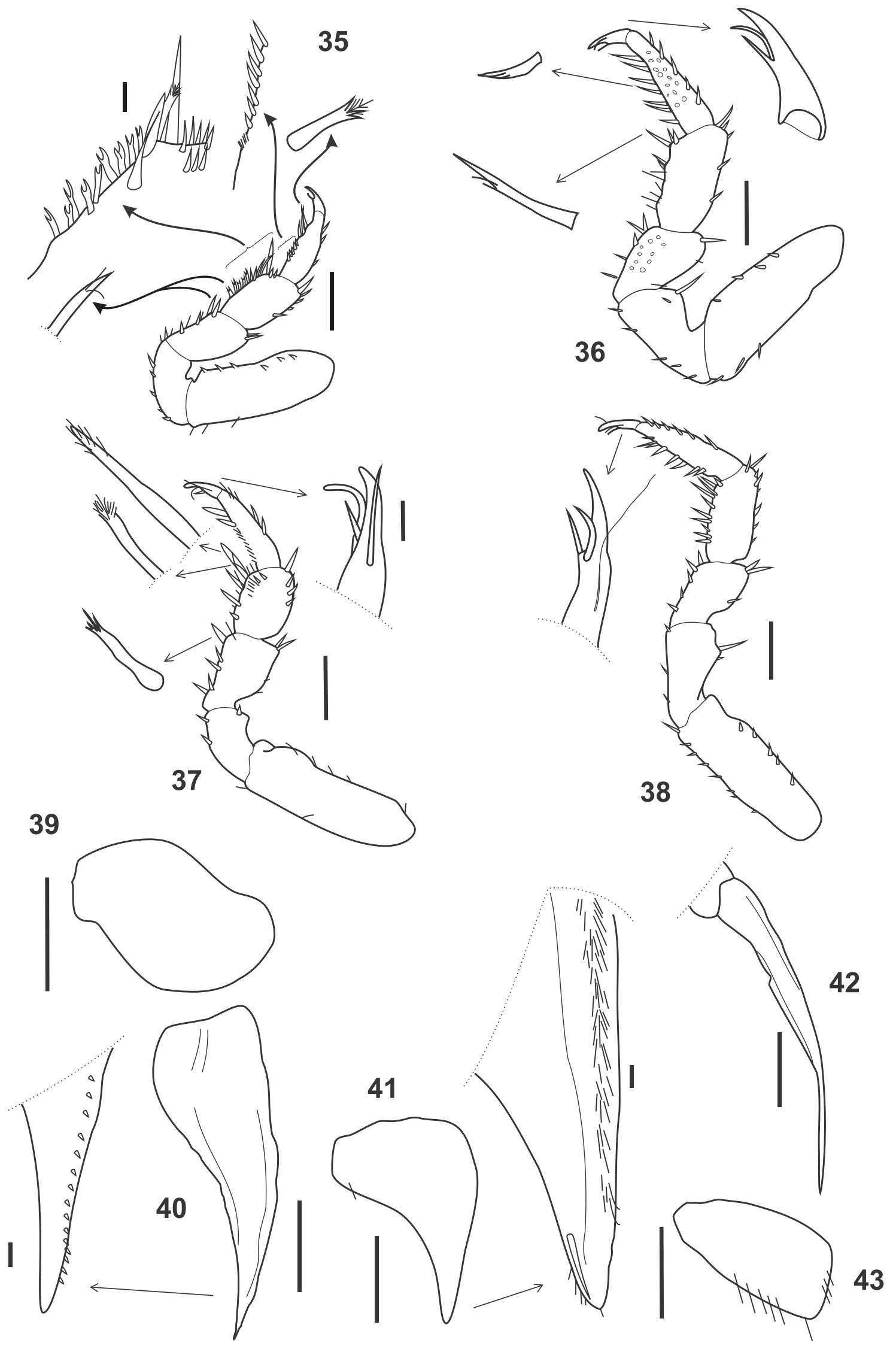

Figs. 35-43. Trichorhina crassisetae sp. nov. Male: 35, pereopod I; 36, pereopod VII. Female: 37, pereopod I; 38, pereopod VII. Scale bars: Figs 35-38, $0.1 \mathrm{~mm}$; arrowed details, $0.01 \mathrm{~mm}$; 39, exopod of pleopod I; 40, endopod of pleopod I; 41, exopod of pleopod II; 42, endopod of pleopod II; 43, exopod of pleopod V. Scale bars: Figs 39-43, $0.1 \mathrm{~mm}$; arrowed details, $0.01 \mathrm{~mm}$. 
II-V of peduncle without inferior groove; 2) exite of maxillulae with eight teeth, of which two bifid (all teeth undivided in T. pubescens). Promptly distinguishable from all other species of the genus by eyes with eight ommatidia.

Etymology. From Latin crassus $=$ thick + seta $=$ bristle, due to the stout bristles in antenna.

\section{Trichorhina lenkoi sp. nov.} (Figs 3, 44-57)

Type material. Holotype $\widehat{\partial}$, BRAZIL, São Paulo: São Roque, Araçariguama, in the leaf mold, 11.IV.1970, K. Lenko col. (MNRJ 4115). Paratypes: 4^, 2 , , same data as holotype (MNRJ 4116).

Diagnosis. Pigmentation of body brown. Eyes with five ommatidia light brown. Exite of maxillulae with six undivided teeth plus one bifid tooth.

Measurements. Male, length: $3.03 \mathrm{~mm}$, width: $1.10 \mathrm{~mm}$; female, length: $2.34 \mathrm{~mm}$, width: $0.96 \mathrm{~mm}$.

Description. Pigmentation of body brown, with small dark brown spots in head. Eyes light brown with five ommatidia, not contiguous. Pereonite I with anterior margins reaching the eyes. Cephalic lateral lobes small, shorter than median lobe which has apex rounded and straight sides (Fig. 44). Pleon outline continuous with pereon; telson subtriangular with sides slightly convex. Surface with hexagonal plates. Pereon, pleon and telson covered with fan-shaped scale-setae (Fig. 46), with four axial rods. Noduli laterales (Fig. 45) with featureless base. Pereonite VII with only one nodulus lateralis on each side. Position of noduli laterales as illustrated (Fig. 3). Antennula with distal joint with about five aesthetascs. Antenna (Fig. 47) stretched reaches posterior margin of pereonite II. Second joint of antennal peduncle without crest in outer border and without dorsal keel. Second joint of antennal flagellum without groove. Left mandible (Fig. 48) without rods between molar and incisory processes. Number of penicils in molar process of left mandibles one (Fig. 48), right one (Fig. 49). Outer group of exite of maxillulae with three teeth. Inner group of exite of maxillulae with four teeth: one bifid (Fig. 50). Maxilla with inner lobe narrower than outer lobe. Sensilla on the inner lobe. (Fig. 51). Endite of maxilliped with two small teeth in distal outer border, and with inner distal border smooth (Fig. 52). Pleopods without respiratory areas.

Male. Pereopods I (Fig. 53) and VII (Fig. 54) without apparent sexual dimorphism. Endopod of pleopod I with distal half slightly turned to the outside, apex simple (Fig. 55). Pleopod II with exopod triangular (Fig. 57); endopod with distal half slender (Fig. 56).

Remarks. Trichorhina lenkoi sp. nov. is distinguished from other species with four to six ommatidia as follows: from T. acuta by 1) molar process of mandibles with one penicil (six in T. acuta);2) exite of maxillulae with six undivided teeth and one bifid (two of inner group bifid in T. acuta). From T. argentina by 1) antenna shorter; 2) eyes light brown (black in $T$. argentina);3) coxal plates without glandular pores. From $T$. australiensis by 1) exite of maxillulae with six undivided teeth and one bifid (in T. australiensis nine, inner group with all bifid); 2) presence of frontal lobe. From T. barbouri by second joint of antennal flagellum without groove and tegument smooth. From T. biumbonata sp. nov. by 1) second joint of antennal peduncle without crest in outer border; 2) molar process of mandibles with one penicil (five to seven in $T$. biumbonata). From $T$. hospes by 1) exite of maxillulae with six undivided teeth and one bifid (in T. hospes nine, two bifid); 2) endite of maxilliped with two teeth in outer distal border (without teeth in T. hospes). From T. pallida by 1) molar process of mandibles with one penicil (two in T. pallida); 2) exite of maxillulae with six undivided teeth and one bifid (two of inner group bifid in T. pallida). From T. papillosa by 1) molar process of mandibles with one penicil (three in T. papillosa); 2) exite of maxillulae with six undivided teeth and one bifid (two bifid in T. papillosa); 3) endite of maxilliped with two teeth in outer distal border and one in inner distal border. From T. paraensis by 1) exite of maxillulae with six undivided teeth and one bifid (in T. paraensis eight, two bifid); 2) endite of maxilliped with two teeth in distal outer border (with one tooth in distal outer border and one tooth in inner border in T. paraensis). From $T$. silvestrii by 1) molar process of both mandibles with one penicil (with three penicils in T. silvestrii); 2) exite of maxillulae with six undivided teeth and one bifid (in T. silvestrii eight, two bifid). From $T$. vandeli by 1) antennula with distal joint with about five aesthetascs (with seven to eight aesthetascs in $T$. vandeli); 2) exite of maxillulae with six undivided teeth and one bifid (in T. vandeli eight, two bifid).

Etymology. Species named after Karol Lenko, who collected the type series, and many other Brazilian Oniscidea.

\section{Trichorhina myrmecophila sp. nov. (Figs 4, 58-78)}

Type material. Holotype $\widehat{\jmath}$, BRAZIL, São Paulo: Barueri, in nest of Camponotus rufipes (Fabricius, 1775) (Hymenoptera, Formicidae), 14.X.1967, K. Lenko col. (MNRJ 4117). Paratypes: $3 ð ̋$, 18 , , same data as holotype (MNRJ 4118).

Diagnosis. Pigmentation of body pale yellow. Eyes with five black ommatidia. Pleopod I of male with exopod slightly rounded; endopod with apex with row of micro-setae.

Measurements. Male, length: $3.00 \mathrm{~mm}$, width: $1.00 \mathrm{~mm}$; female, length: $2.30 \mathrm{~mm}$, width: $0.92 \mathrm{~mm}$.

Description. Pigmentation of body faint, pale yellow, with small brown spots in head. Eyes black with five ommatidia. Head partly sunken in pereonite 

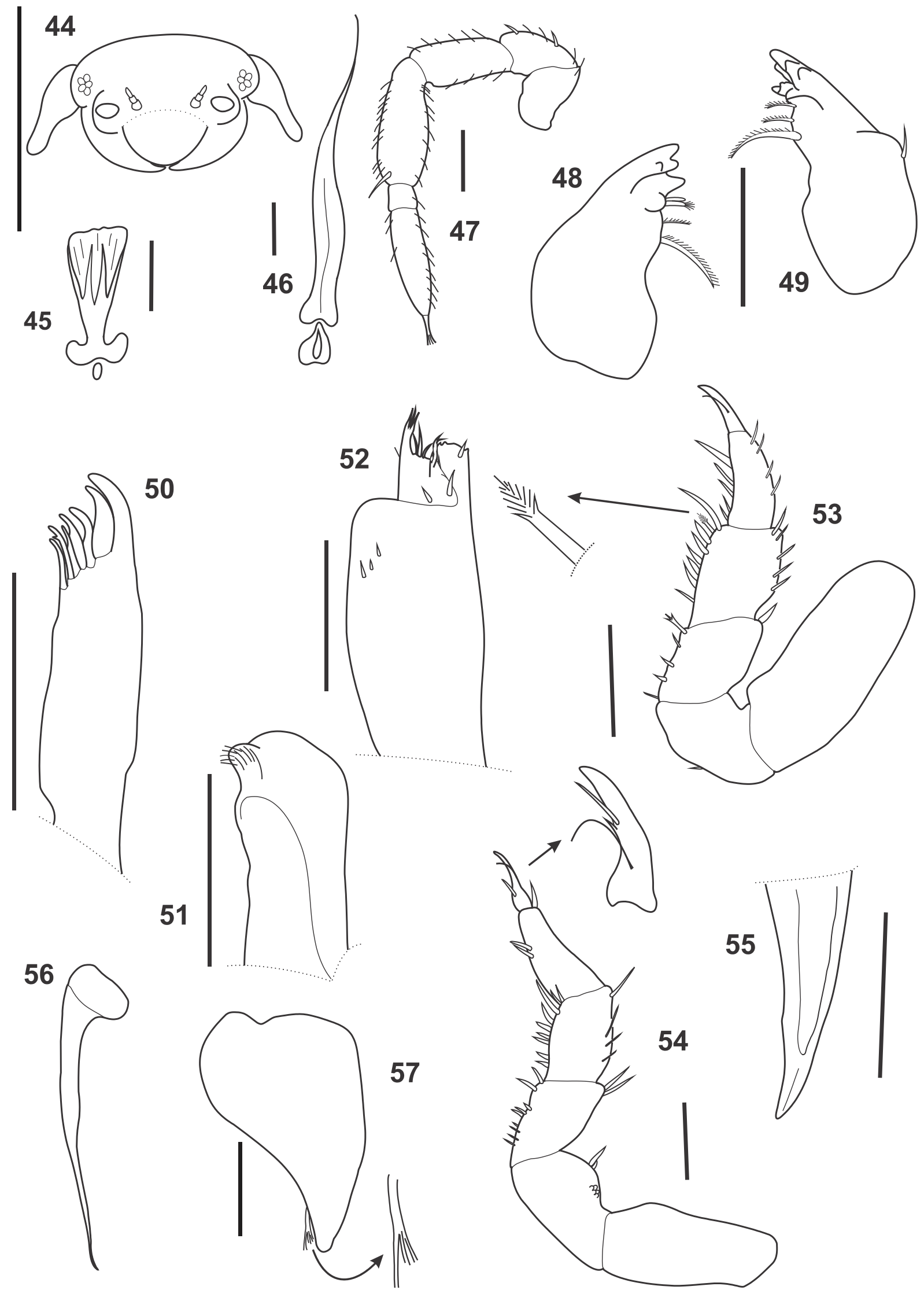

Figs. 44-57. Trichorhina lenkoi sp. nov., male: 44, cephalothorax, frontal view; 45, nodulus lateralis; 46, fan-shaped scale-seta of pereonite; 47, antenna; 48, left mandible; 49, right mandible; 50, exite of maxillula; 51, maxilla; 52, maxilliped. Scale bars: Fig. 44, 0.5 mm; Figs 45-46, 0.01 mm; Figs 47-52, $0.1 \mathrm{~mm}$; 53, pereopod I; 54, pereopod VII; 55, endopod of pleopod I, detail; 56, endopod of pleopod II; 57, exopod of pleopod II. Scale bars: $0.1 \mathrm{~mm}$. 
I, anterior margins of pereonite I reaching the eyes. Cephalic lateral lobes slightly ahead of median lobe which has apex rounded and straight sides (Figs 59, 60). Pleon slightly narrower than pereon, pleonites III-V with well developed points (Fig. 58). Body surface with hexagonal plates. Pereon, pleon and telson covered with fan-shaped scale-setae bearing two axial rods (Fig. 63). Noduli laterales with featureless base (Fig. 62). Pereonite VII with only one nodulus lateralis on each side. Position of noduli laterales as illustrated (Fig. 4). Antennula with middle joint much smaller than others, distal joint with five aesthetascs (Fig. 61). Antenna (Fig. 64) stretched reaches posterior margin of pereonite II. Second joint of antennal peduncle without crest in outer border and without dorsal keel. Second joint of antennal flagellum with a slightly transversal groove. Left mandible (Fig. 65) without rods between molar and incisory processes. Number of penicils in molar process of left mandibles one (Fig. 65), right one (Fig. 66). Outer group of exite of maxillulae with three teeth. Inner group of exite of maxillulae with four simple teeth (Fig. 67). Maxilla with inner lobe narrower than outer lobe wich is apically truncate. Sensilla on the inner lobe (Fig. 68). Endite of maxilliped with two small teeth in outer distal border, and irregular inner distal border (Fig. 69). Pleopods without respiratory areas.

Male. Pereopods I (Fig. 70) and VII (Fig. 71) without apparent sexual dimorphism (see pereopods I and VII of female in figures 73 and 72, respectively). Carpus of pereopod I of male without bristle field. Pleopod I with exopod rounded (Fig. 74); endopod (Fig. 75) with distal half slightly turned to the outside and apex armed with a short row of micro-setae parallel to the inner border. Pleopod II with triangular exopod (Fig. 77); endopod with distal half gradually tapered (Fig. 76). Pleopod V with sub-rectangular exopod (Fig. 78).

Remarks. Trichorhina myrmecophila sp. nov. is distinguished from other species with eye with four to six ommatidia as follows: from T. acuta by 1) molar process of mandibles with one penicil (six in T. acuta); 2) exite of maxillulae with seven undivided teeth (two of inner group bifid in T. acuta). From T. argentina by 1) exopod of pleopod I of male rounded (ovoid in T. argentina); 2) endopods of uropods relatively longer. From $T$. australiensis by 1) antennula with joints of different proportions; 2) exite of maxillulae with seven undivided teeth (in T. australiensis nine, five of which bifid); 3) exopod of pleopod I of male rounded (narrowed in inner side in T. australiensis). From T. barbouri by 1) second joint of antennal flagellum without groove and tegument smooth. From T. biumbonata sp. nov. by 1) second joint of antennal peduncle without crest in outer border; 2) molar process of mandibles with one penicil (with about seven in T. biumbonata); 3) endite of maxilliped with two teeth in upper outer margin (one in T. biumbonata); 4) pereopod I of male with setae undivided (with up to four points in T. biumbonata). From T. hospes by 1) antennula with distal joint with five aesthetases (six in $T$. hospes);2) exite of maxillulae with seven undivided teeth (in T. hospes nine, two bifid). From T. lenkoi sp. nov. by 1) pigmentation of body pale yellow (light brown in $T$. lenkoi); 2) eyes black (light brown in T. lenkoi); 3) pleon slightly narrower than pleon (continuous with pereon in T. lenkoi); 4) endopod of pleopod I of male with row of micro-setae in apex. From T. pallida by 1) molar process of mandibles with one penicil (two in T. pallida); 2) exite of maxillulae with seven undivided teeth (in $T$. pallida seven, two bifid); 3) exopod of pleopod I of male rounded (elliptic in T. pallida). From T. papillosa by 1) molar process of mandibles with one penicil (three in $T$. papillosa);2) exite of maxillulae with seven undivided teeth (in T. papillosa seven, two bifid); 3) endite of maxilliped with two teeth in distal outer border. From $T$. paraensis by 1) pereon, pleon and telson with fan-shaped scale-setae (with ovoid scale-setae in T. paraensis); 2) endite of maxilliped with two teeth in outer distal border (with one tooth in T. paraensis). From T. silvestrii by 1) distal joint of antennula with five aesthetascs (four in $T$. silvestrii);2) exite of maxillulae with seven undivided teeth (in T. silvestrii eight, two bifid). From T. vandeli by 1) distal joint of antennula with five aesthetascs (seven to eight in T. vandeli);2) molar process of mandibles with one penicil (with a group of many penicils in $T$. vandeli).

Etymology. Species name stems from Greek and refers to the collecting of the type series in nest of ants.

\section{Trichorhina orensis sp. nov.} (Figs 5, 79-94)

Type material. Holotype $\widehat{\jmath}$, BRAZIL, Rio de Janeiro: Ilha de Itacuruçá, Praia dos Mocambos (supra tidal line, in garbage), 15.XII.1973, A. L. Castro \& B. Prazeres col. (MNRJ 4119). Paratypes: $12 \hat{\jmath}, 41$, same data as holotype (MNRJ 4120).

Diagnosis. Body unpigmented. Eyes with five brown ommatidia. Molar process of mandible with one penicil. Exite of maxillulae with seven teeth, two bifid. Measurements. Male, length: $2.48 \mathrm{~mm}$, width: $0.83 \mathrm{~mm}$; female, length: $2.89 \mathrm{~mm}$, width: $0.99 \mathrm{~mm}$.

Description. Body unpigmented. Eyes brown with five ommatidia. Pleon outline continuous with pereon (Fig. 79); telson subtriangular with rounded apex of sides slightly concave. Pereon, pleon and telson covered with fan-shaped scale-setae. In the posterior margins of pereonites they are large and wide, alternating with small and narrow ones, and in the lateral margins they are small. Both median axes of fan-shaped scale-setae evident, as well as the secondary supporting axioles (Fig. 83). Noduli laterales with simple base (Fig. 84). Pereonite VII with one nodulus lateralis on each side. Position of noduli laterales as illustrated (Fig. 5). Uropods with a tuft of bristles in apex of exopod. Distal joint of antennula with about eight aesthetascs (Fig. 85). Second joint of antennal peduncle without 

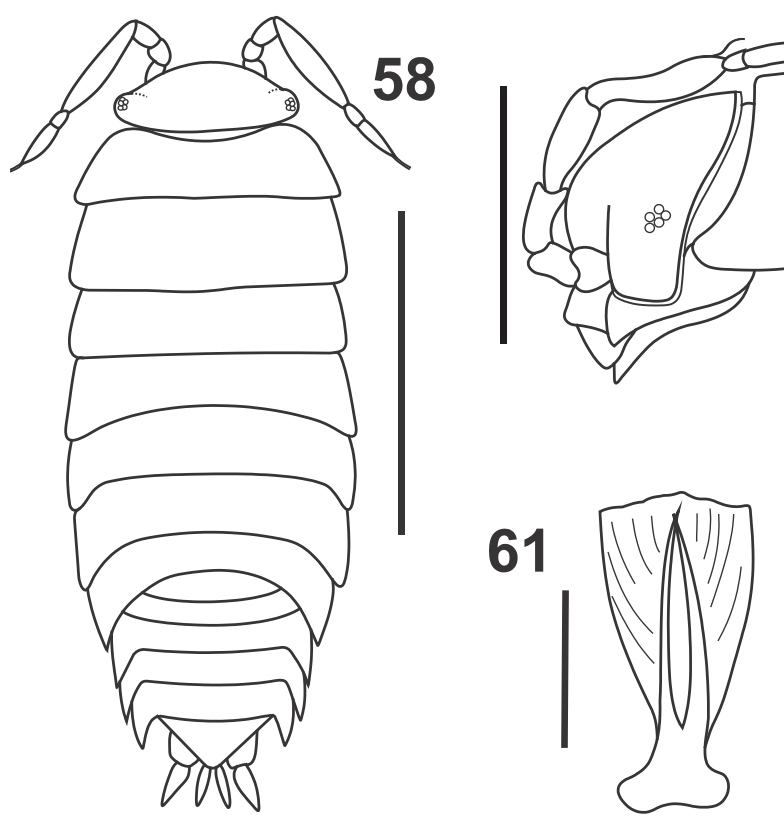

59
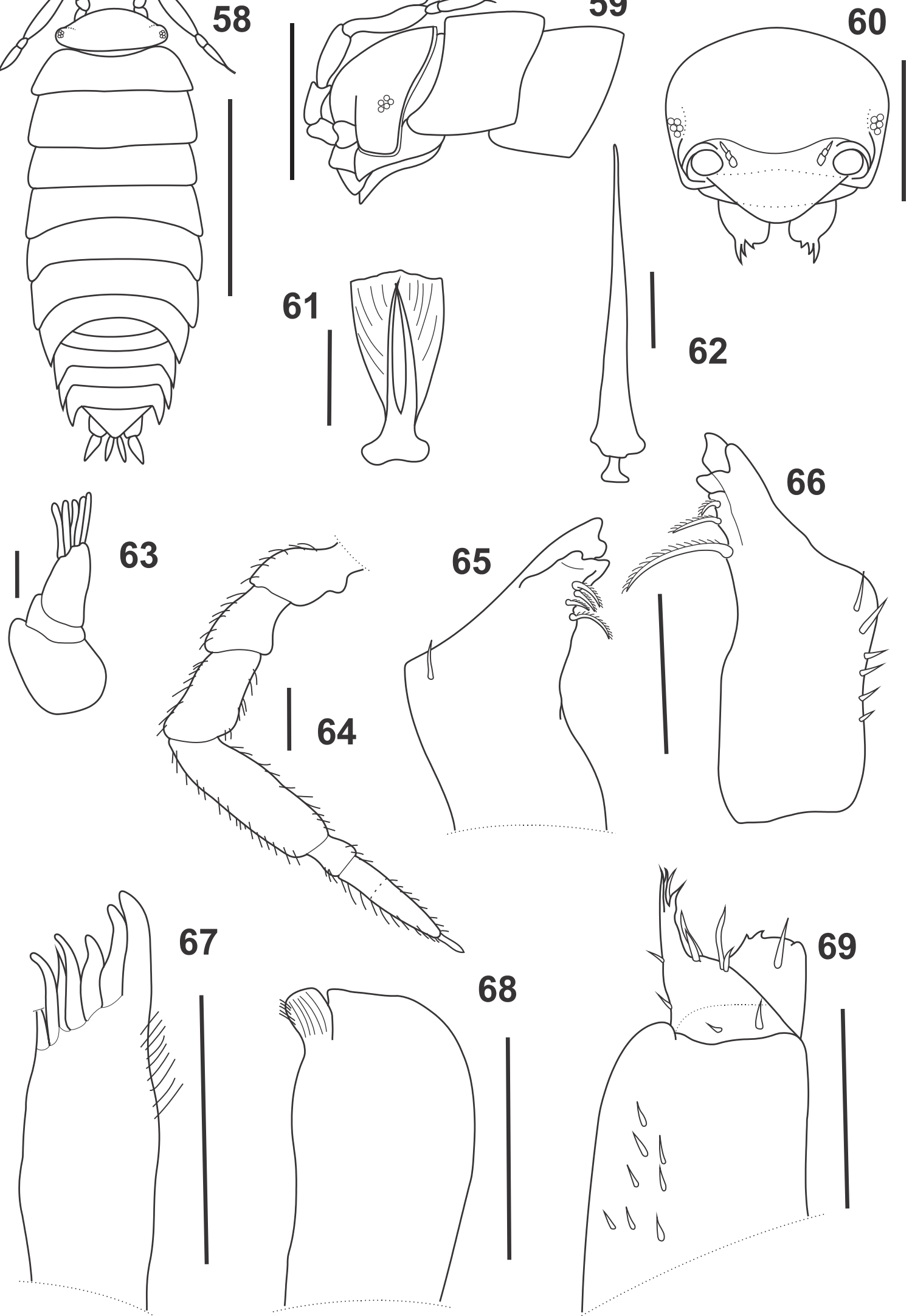

67
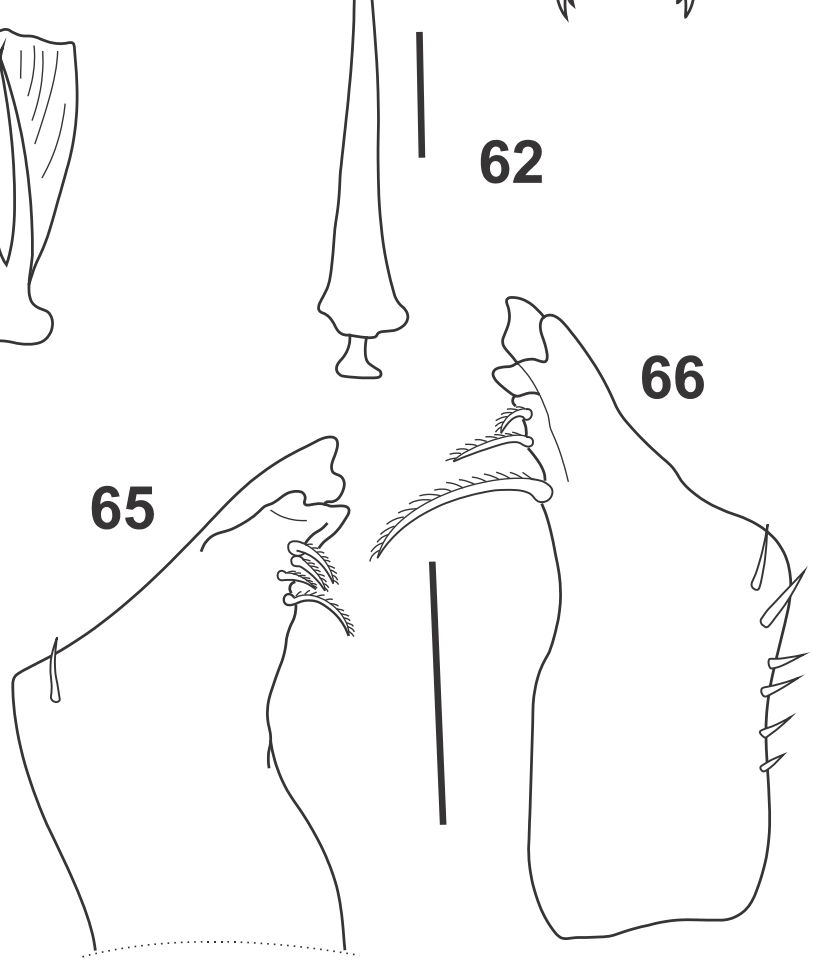

Figs. 58-69. Trichorhina myrmecophila sp. nov. Female, habitus: 58, dorsal; 59, cephalothorax and two first pereonites, lateral view; 60, cephalothorax, frontal view. Male: 61, antennula; 62, nodulus lateralis; 63, fan-shaped scale-seta of pereonite; 64, antenna; 65, left mandible; 66, right mandible; 67, exite of maxillula; 68, maxilla; 69, maxilliped. Scale bars: Fig. 58, 1 mm; Figs 59-60, 0.5 mm; Figs 62-63, 0.01 mm; Figs 61, 64-69, $0.1 \mathrm{~mm}$ 


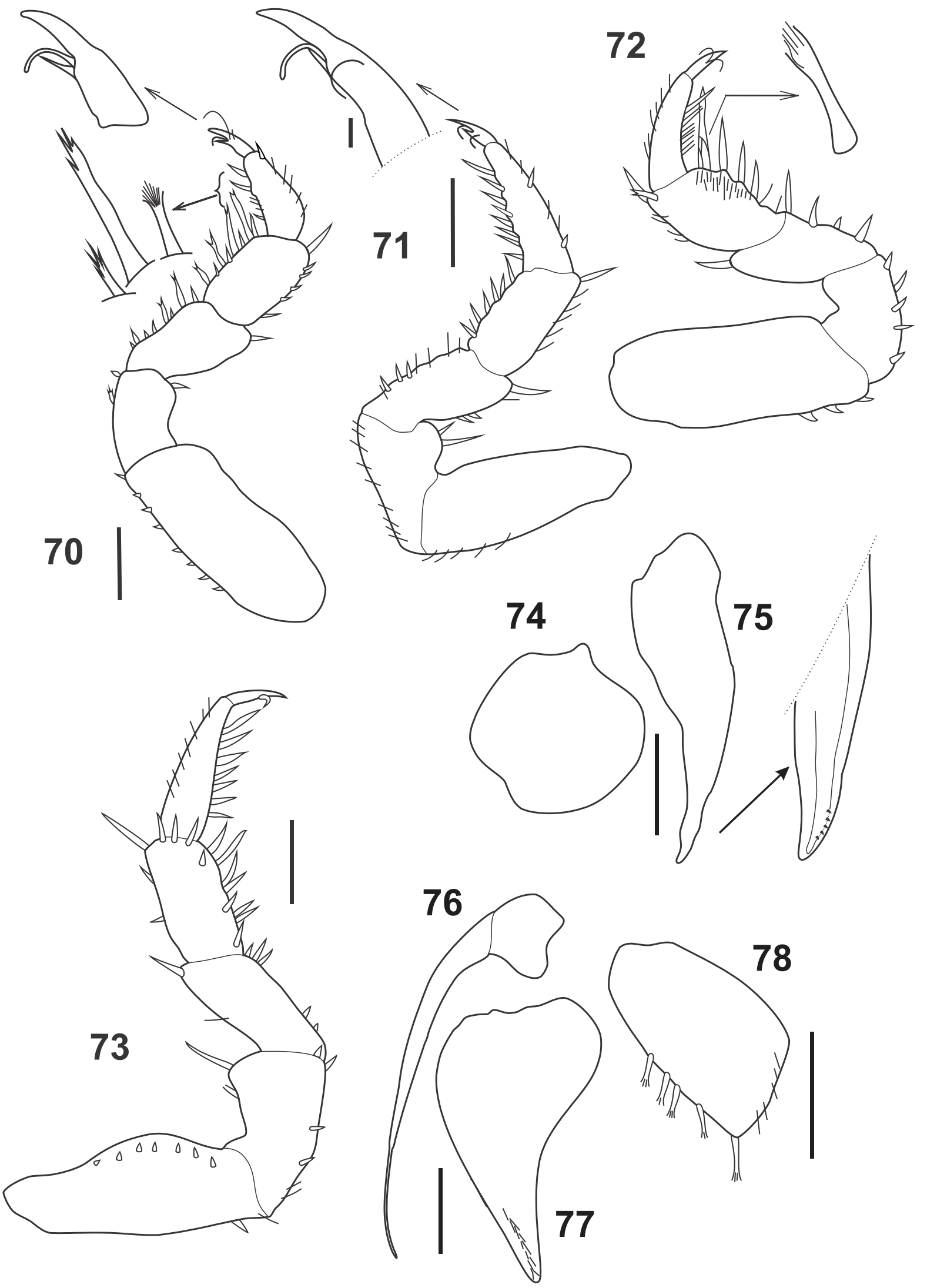

Figures 70-78. Trichorhina myrmecophila sp. nov. Male: 70, pereopod I; 71, pereopod VII. Female: 72, pereopod VII; 73, pereopod I. Male: 74 exopod of pleopod I; 75, endopod of pleopod I; 76, endopod of pleopod II; 77, exopod of pleopod II; 78, exopod of pleopod V. Scale bars: Figs $70-78,0.1 \mathrm{~mm}$; arrowed details, $0.01 \mathrm{~mm}$. 
crest in outer border and without dorsal keel. Second joint of antennal flagellum without groove (Fig. 82). Left mandible without rods between molar and incisory processes. Number of penicils in molar process of left mandibles one, right one (Fig. 86). Outer group of exite of maxillulae with three teeth. Inner group of exite of maxillulae with four teeth: two bifid (Fig. 87). Maxilla with inner lobe narrower than outer lobe. Sensilla on the inner lobe, with a sinuous median margin (Fig. 88). Endite of maxilliped with two small teeth in distal outer border, and with inner distal border smooth (Fig. 89). Pleopods without respiratory areas.

Male. Carpus of pereopod I of male (Fig. 90) with bristle field. Pereopod VII (Fig. 91) without sexual dimorphism. Pleopod I with endopod with distal half turned to the outside and apex slightly crenulate (Fig. 92). Pleopod II (Fig. 93) with triangular exopod; endopod with distal half strongly narrowed. Pleopod V with subtriangular exopod (Fig. 94).

Remarks. Trichorhina orensis sp. nov. is distinguished from other species with four to six ommatidia, as follows: from T. acuta by molar process of mandibles with one penicil (six in T. acuta). From T. argentina by 1) body unpigmented (purplish uniform pigmentation in $T$. argentina); 2) brown ommatidia (black in T. argentina); 3) coxal plates without glandular pores. From T. australiensis by exite of maxillulae with seven teeth, of which two bifid (in T. australiensis nine, five bifid), and endite of maxilliped without tooth in distal inner border. From T. barbouri by second joint of antennal flagellum without groove and tegument smooth. From T. biumbonata sp. nov. by 1) second joint of antennal peduncle without crest in outer border; 2) molar process of mandibles with one penicil (with about seven in T. biumbonata); 3) endite of maxilliped with two teeth in distal outer border (one in T. biumbonata). From $T$. hospes by exite of maxillulae with seven teeth, of which two bifid (in T. hospes nine, two bifid). From $T$. lenkoi sp. nov. by endite of maxilliped without teeth in inner distal border, and dactylus of pereopod I of male with inner seta larger. From T. myrmecophila sp. nov. by the inner group of exite of maxillulae with two bifid teeth (four undivided teeth in T. myrmecophila), and endopod of pleopod II of male without row of scale-setae. From T. pallida by the molar process of mandibles with one penicil (two in T. pallida), and endopod of pleopod I of male with distal half turned to the outside (straight in T. pallida). From T. papillosa by the molar process of mandibles with one penicil (three in T. papillosa), and endite of maxilliped with two teeth in outer distal border. From T. paraensis by exite of maxillulae with seven teeth, of which two bifid (in T. paraensis eight, two bifid), and endite of maxilliped without teeth in inner distal border (with one tooth in inner distal border in T. paraensis). From T. silvestrii by distal joint of antennula with about eight aesthetascs (four in T. silvestrii), and molar process of mandibles with one penicil (three in T. silvestrii).
From $T$. vandeli by molar process of mandibles with one penicil (with a group of many penicils in $T$. vandeli), and exite of maxillulae with seven teeth, of which two bifid (in T. vandeli eight, two bifid).

Etymology. From Latin ora $=$ beach, referring to microhabitat where the individuals were collected.

\section{Trichorhina sexdens sp. nov.}

(Figs 6, 95-107)

Type material. Holotype $\hat{\sigma}$, BRAZIL, São Paulo: Ilha dos Búzios, 16.X to 04.XI.1963, K. Lenko col. (MNRJ 4121). Paratypes: $3 \hat{\jmath}, 6$, same data as holotype (MNRJ 4122).

Diagnosis. Body brown. Eyes with four dark brown ommatidia. Molar process of mandibles with one penicil. Exite of maxillulae with six simple teeth.

Measurements. Male, length: $2.13 \mathrm{~mm}$, width: $0.65 \mathrm{~mm}$; female, length: $2.13 \mathrm{~mm}$, width: $0.71 \mathrm{~mm}$.

Description. Body brown, with small dark brown spots in head. Eyes dark brown with four ommatidia. Head narrowed in the anterior half and not sunken in pereonite I. Cephalic lateral lobes very small, shorter than the median lobe, which has rounded apex (Figs 95, 96). Body surface with plates. Pereon, pleon and telson covered with fan-shaped scale-setae. Noduli laterales with simple base. Each side of pereonite VII with one nodulus lateralis. Position of noduli laterales as illustrated (Fig. 6). Second joint of antennal peduncle without crest in outer border and without keel in dorsal side. Second joint of antennal flagellum entire (Fig. 97). Left mandible (Fig. 98) without rods between molar and incisory processes. Number of penicils in molar process of left mandibles one (Fig. 98), right one. Outer group of exite of maxillulae with three teeth. Inner group of exite of maxillulae with three undivided teeth (Fig. 99). Endite of maxilliped (Fig. 100) with two small teeth in distal outer border, and one small tooth in distal inner border. Pleopods without respiratory areas.

Male. Pereopods I (Fig. 101) and VII (Fig. 102) without sexual dimorphism. Pleopod I with subrectangular exopod (Fig. 103); endopod with distal half slightly turned to the outside and apex armed with a short row of scale-setae parallel to the inner border (Fig. 104). Pleopod II with triangular exopod (Fig. 106); endopod with distal half slender (Fig. 105). Pleopod V with subtriangular exopod with five large bristles (Fig. 107).

Remarks. Trichorhina sexdens sp. nov. is distinguished from other species with four to five ommatidia as follows: from T. acuta by 1) exite of maxillulae with six undivided teeth (in T. acuta seven, with two bifid); 2) endite of maxilliped with two teeth in inner distal border and one tooth in outer distal border (without teeth in outer distal border in T. acuta). From T. barbouri by 1) tegument smooth (granulous in $T$. barbouri); 2) second joint of antennal flagellum without groove. From $T$. hospes by 1) exite of maxillulae with 


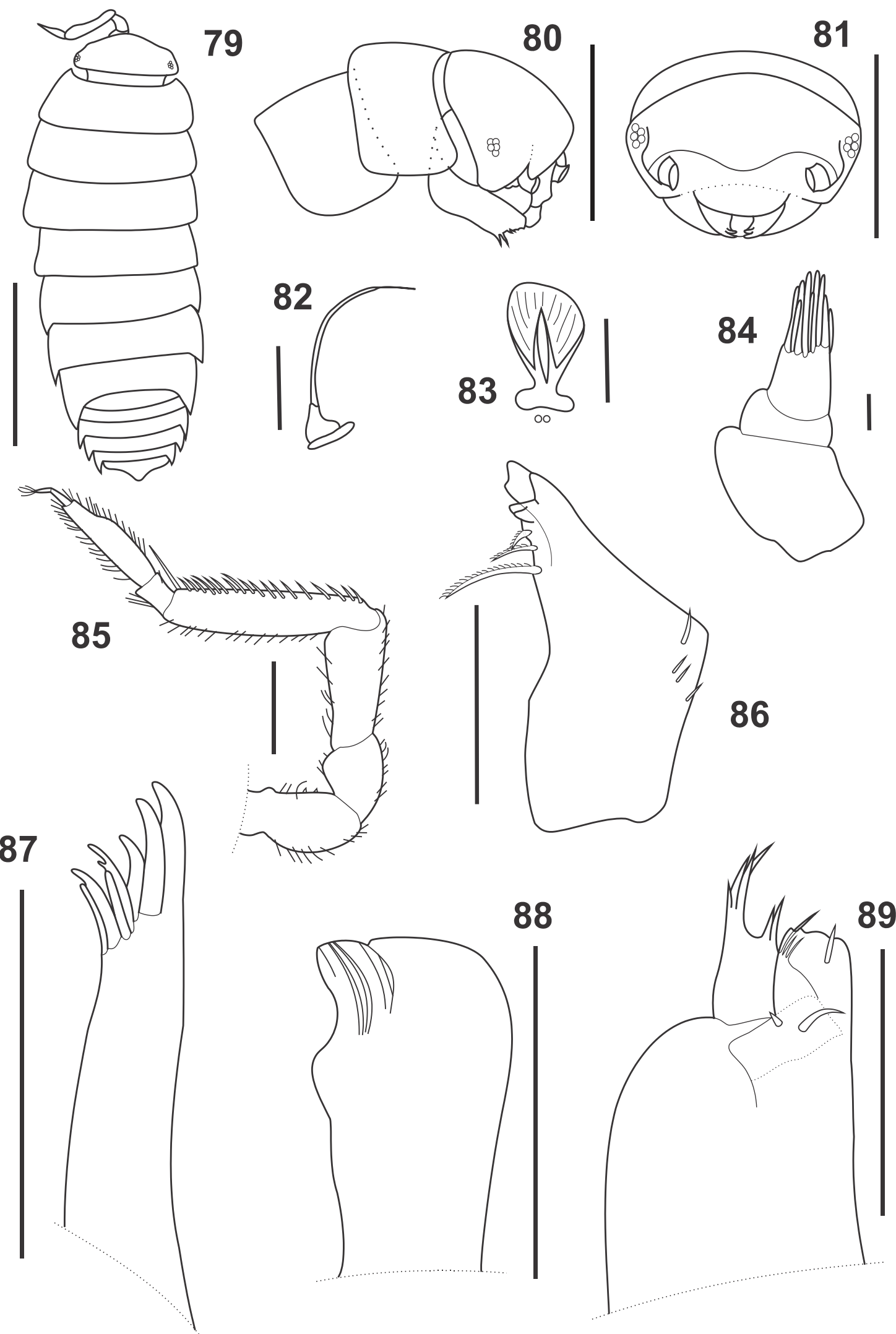

Figs. 79-89. Trichorhina orensis sp. nov. Female, habitus: 79, dorsal; 80, cephalothorax and two first pereonites, lateral view; 81, cephalothorax, frontal view. Male: 82 , antenna; 83 , fan-shaped scale-seta of pereonite; 84 , nodulus lateralis; 85 , antennula; 86 , right mandible; 87 , exite of maxillula; 88, maxilla; 89, maxilliped. Scale bars: Fig. 79, 1 mm; Figs 80-81, 0.5 mm; Figs 83-84, 0.01 mm; Figs 82, 85-89, 0.1 mm. 

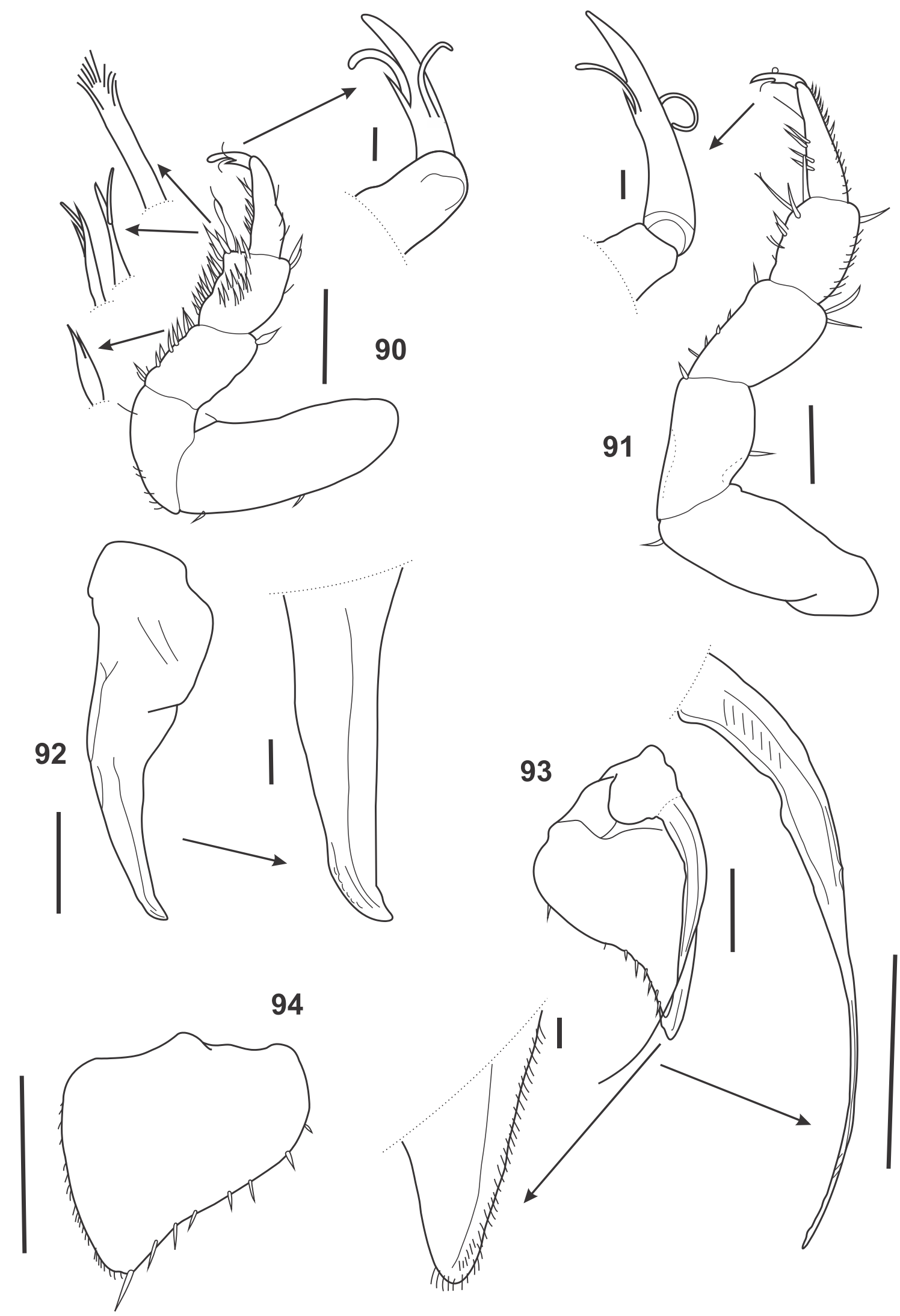
six undivided teeth (in T. hospes nine, with two bifid); 2) endite of maxilliped with two teeth in inner distal border and one tooth in outer distal border. From $T$. paraensis by 1) eyes with dark brown ommatidia (light brown in T. paraensis); 2) exite of maxillulae with six undivided teeth (in T. paraensis eight, two bifid). From T. silvestrii by 1) absence of rods between molar and incisory processes of left mandible; 2) molar process of mandible with one penicil (three in T. silvestrii); 3) exite of maxillulae with six undivided teeth (in $T$. silvestrii eight, of which two bifid). From $T$. vandeli by 1) molar process of mandibles with one penicil (many in T. vandeli); 2) exite of maxillulae with six undivided teeth (in T. vandeli eight, of which two bifid); 3) exopod I of male subrectangular (subtriangular in $T$. vandeli). From $T$. biumbonata sp. nov., $T$. lenkoi sp. nov., $T$. myrmecophila sp. nov. and $T$. orensis $\mathrm{sp}$. nov. mainly by the eyes with four ommatidia (five in these species).

The species with three ommatidia [e.g. T. triocellata Ferrara \& Taiti, 1985 and T. squamata (Verhoeff, 1933)] have eyes with a conspicuous triangular conformation of ommatidia.

Etymology. Species name originates from Latin, meaning six teeth, due to dentition of maxillular exite.

\section{Trichorhina tropidocerata sp. nov.} (Figs 7, 108-124)

Type material. Holotype $\widehat{\partial}$, BRAZIL, São Paulo: Santos (Ponta da Praia), under bricks and stones $100 \mathrm{~m}$ from fishing station, 27.XI.1963, P. S. Moreira col. (MNRJ 4125). Paratypes: 23 đ , 38ㅇ, same data as holotype (MNRJ 4126).

Diagnosis. Body pale yellow, with small brown spots in head. Eyes with 15 black ommatidia. Molar process of mandibles with seven penicils. Exite of maxillulae with eight simple teeth.

Measurements. Male, length: $3.58 \mathrm{~mm}$, width: $1.33 \mathrm{~mm}$; female, length: $5.04 \mathrm{~mm}$, width: $1.99 \mathrm{~mm}$.

Description. Pigmentation of body faint, pale yellow, with small brown spots in head. Eyes black with 15 ommatidia. Pereonite I with anterior margins reaching the line of the eyes, and lateral lobes slightly ahead of median lobe which has apex rounded and straight sides (Figs 109, 110). Pleon narrower than pereon (Fig. 108), pleonites III-V with well developed epimera; telson triangular and depressed in the middle. Body surface with semi-circular scales. Pereon, pleon and telson covered with fan-shaped scale-setae and two axial rods (Fig. 114). In posterior margins of pereonites they are large and wide, intercalate with small and narrow ones, and in lateral margins they are small. Nodulus lateralis with featureless base (Fig. 115). Pereonite VII with only one nodulus lateralis on each side. Position of noduli laterales as illustrated (Fig. 7). Projected tubercles apically in merus and carpus of pereopods II-VII (Fig. 118). Antenna (Fig. 111) stretched reaches half of pereonite III. Second joint of antennal peduncle with dorsal keel, projecting over third join. Second joint of antennal flagellum with distal groove. Left mandible (Fig. 112) without rods between molar and incisory processes. Number of penicils in molar process of left mandibles seven (Fig. 112), right seven (Fig. 113). Outer group of exite of maxillulae with four teeth, one smaller. Inner group of exite of maxillulae with four simple teeth (Fig. 116). Endite of maxilliped without small teeth in distal outer border; distal border irregular (Fig. 117). Pleopods without respiratory areas.

Male. Pereopods I (Fig. 119) and VII (Fig. 118) without sexual dimorphism. Pleopod I with subtriangular exopod (Fig. 120); endopod with distal half slightly turned to the outside, apex simple (Fig. 121). Pleopod II with exopod subtriangular with rounded apex (Fig. 123); endopod narrowed in second half (Fig. 122). Pleopod V with subtriangular exopod (Fig. 124).

Remarks. Trichorhina tropidocerata sp. nov. is distinguished from Trichorhina lobata Verhoeff, 1946 which has a similar number of ommatidia (13 to 14) by 1) second joint of antennal peduncle with a keel; 2) endite of maxilliped without teeth (with three stout teeth in T. lobata); 3) ischium of pereopod VII of male without keel; 4) scales in pereopods II-VII. Distinguished from all other species of the genus by the eyes composed by 15 ommatidia.

Etymology. Species name comes from Greek tropis $=$ keel and ceras $=$ feeler, due to the strong keel in antennal peduncle.

\section{Trichorhina acuta Araújo \& Buckup, 1994}

Trichorhina acuta ARAÚJO \& BUCKUP, 1994: 130, figs 1-12.

Material examined. BRAZIL, Mato Grosso do Sul: Bonito (Toca do Tamanduá), ふै, 10오, 16.IV.1998, E. Trajano \& J. J. Geoffroy col. (UECE).

Distribution. BRAZIL, Santa Catarina and Rio Grande do Sul; new record for the state of Mato Grosso do Sul.

\section{Key to the species of Trichorhina from Brazil}

1. Ischium of pereopod VII of the male with conspicuous expansion. . . . . . . . . . . T. tatianae Ischium without expansion. . . . . . . . .

2. Eyeless or with only one diminute ommatidium; unpigmented $\ldots \ldots \ldots \ldots \ldots \ldots \ldots \ldots$ At least one well developed ommatidium; color variable . . . . . . . . . . . . . 4

3. Telson acutely pointed; antennary tubercles prominent ..................... T. brasiliensis Telson subtriangular broadly rounded; antennary tubercles not prominent ............. T. pittieri

4. Pereonite VII with two noduli laterales on each side . . . . . . . . . . . . . . 5 Pereonite VII with only one nodulus lateralis on each side ................. 7 
256

SouzA et al.

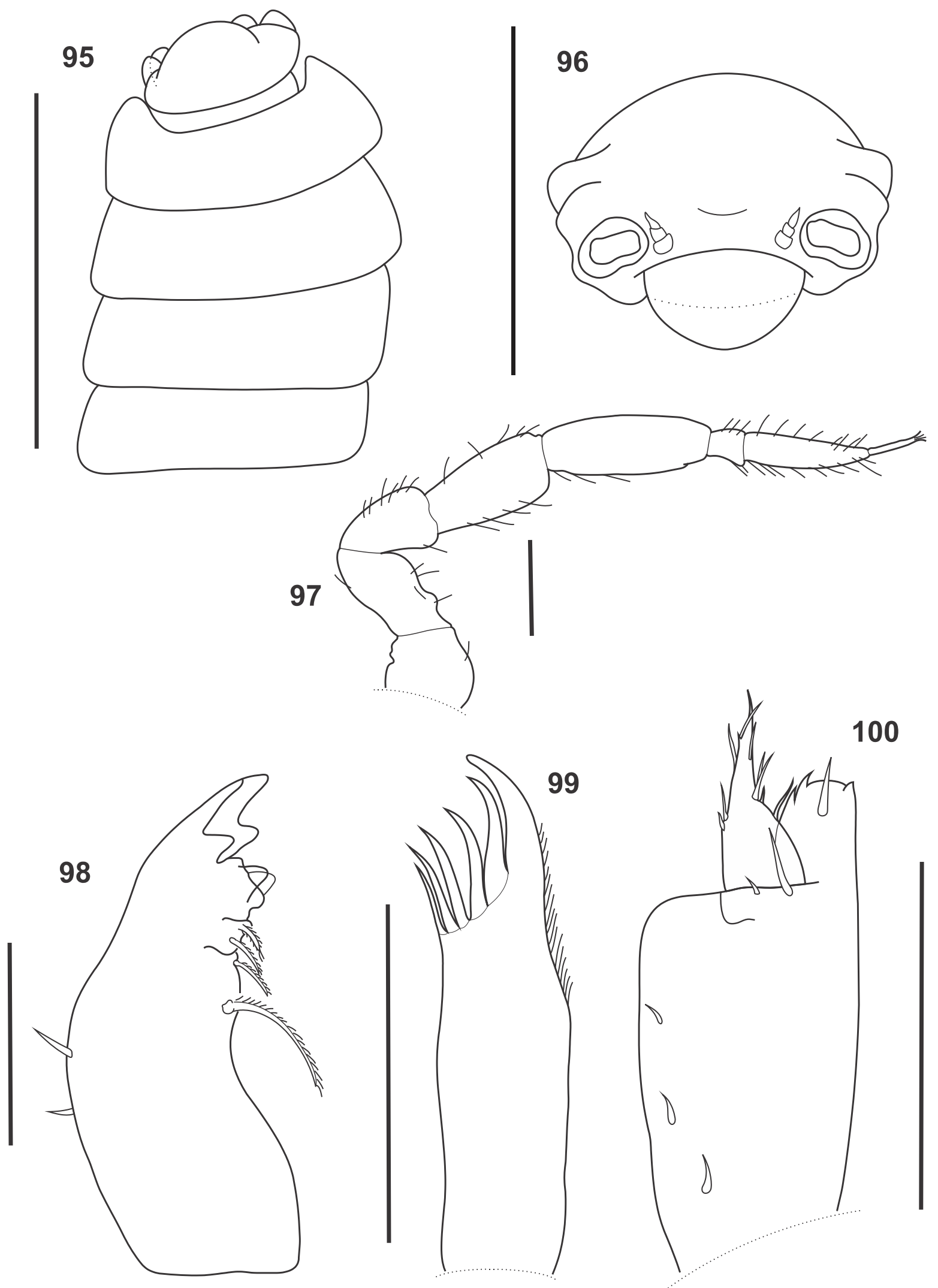

Figs. 95-100. Trichorhina sexdens sp. nov., male: 95, cephalothorax and four first pereonites, dorsal view; 96, cephalothorax, frontal view; 97 , antenna; 98, left mandible; 99, exite of maxillula; 100, maxilliped. Scale bars: Fig. 95, 1 mm; Fig. 96, 0.5 mm; Figs 97-100, 0.1 mm.

Iheringia, Série Zoologia, Porto Alegre, 101(3): 239-261, 30 de Setembro de 2011 


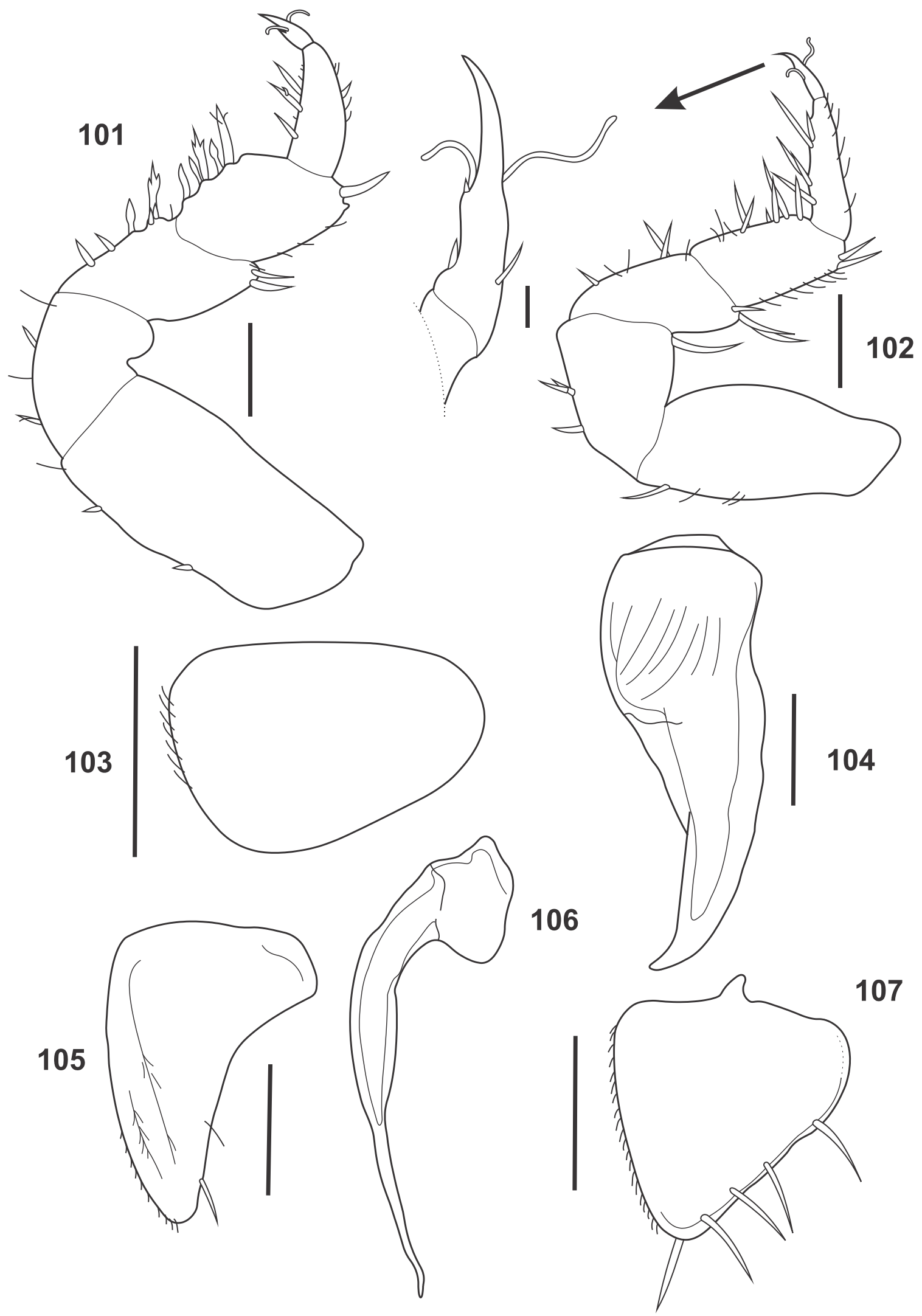

Figs. 101-107. Trichorhina sexdens sp. nov., male: 101, pereopod I; 102, pereopod VII; 103, exopod of pleopod I; 104, endopod of pleopod I; 105, endopod of pleopod II; 106, exopod of pleopod II; 107, exopod of pleopod V. Scale bars: Figs 101-107, $0.1 \mathrm{~mm}$. 

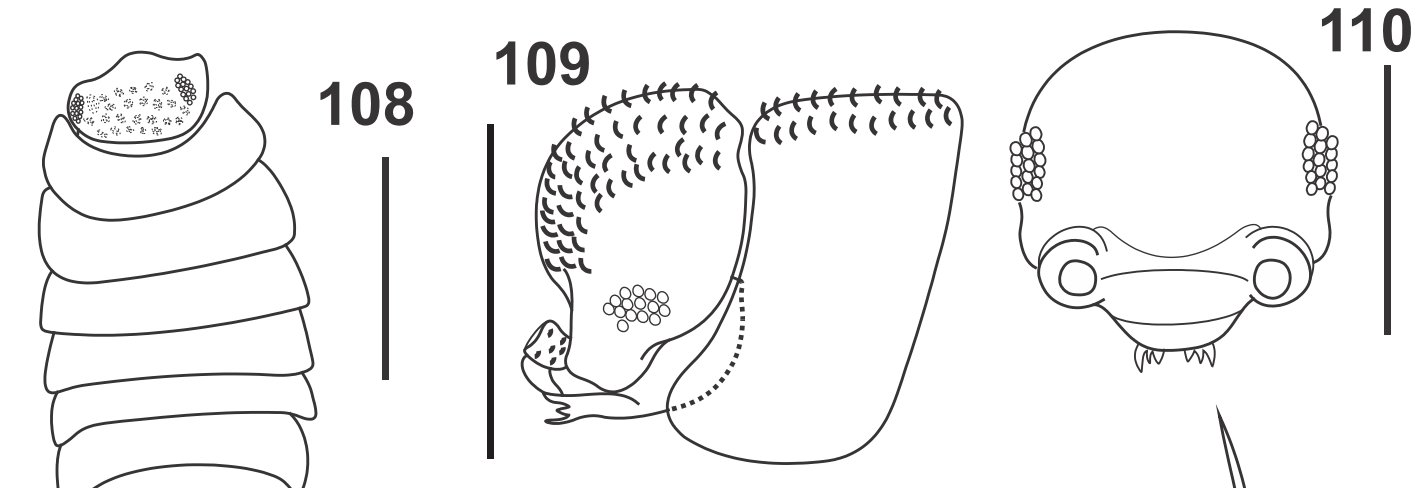

112

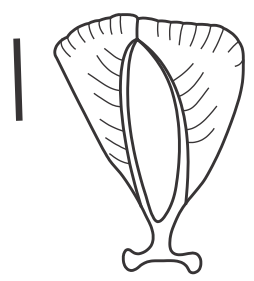

113
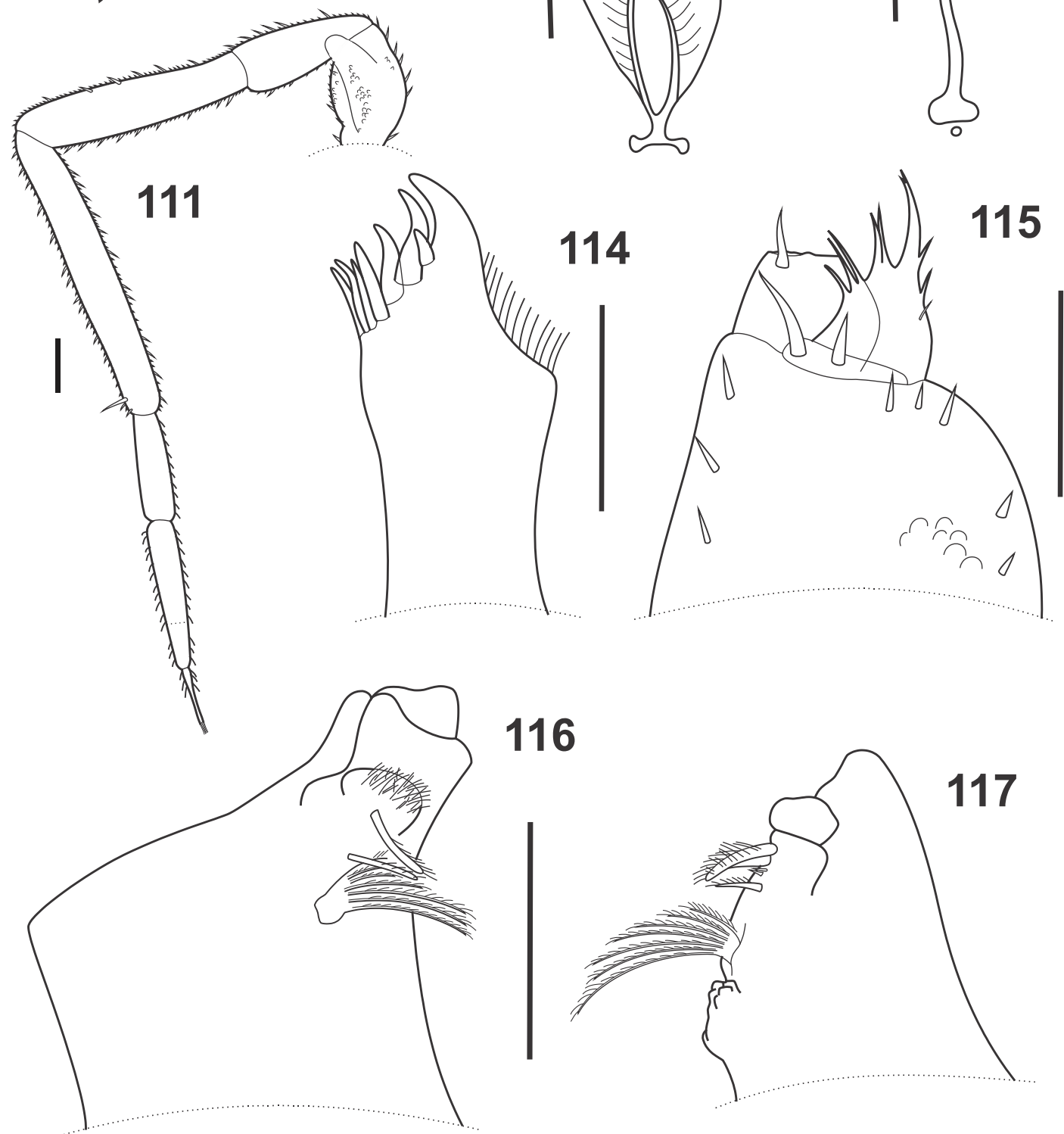

Figs. 108-117. Trichorhina tropidocerata sp. nov. Female, habitus: 108, dorsal; 109, cephalothorax and first pereonite, lateral view; 110, cephalothorax, frontal view. Male: 111, antenna; 112, left mandible; 113, right mandible; 114, fan-shaped scale-seta of pereonite; 115, nodulus lateralis; 116, exite of maxillula; 117, maxilliped. Scale bars: Figs 108-109, 1 mm; Fig. 110, 0.5 mm; Figs 114-115, 0.01 mm; Figs 111-113, 116-117, $0.1 \mathrm{~mm}$ 


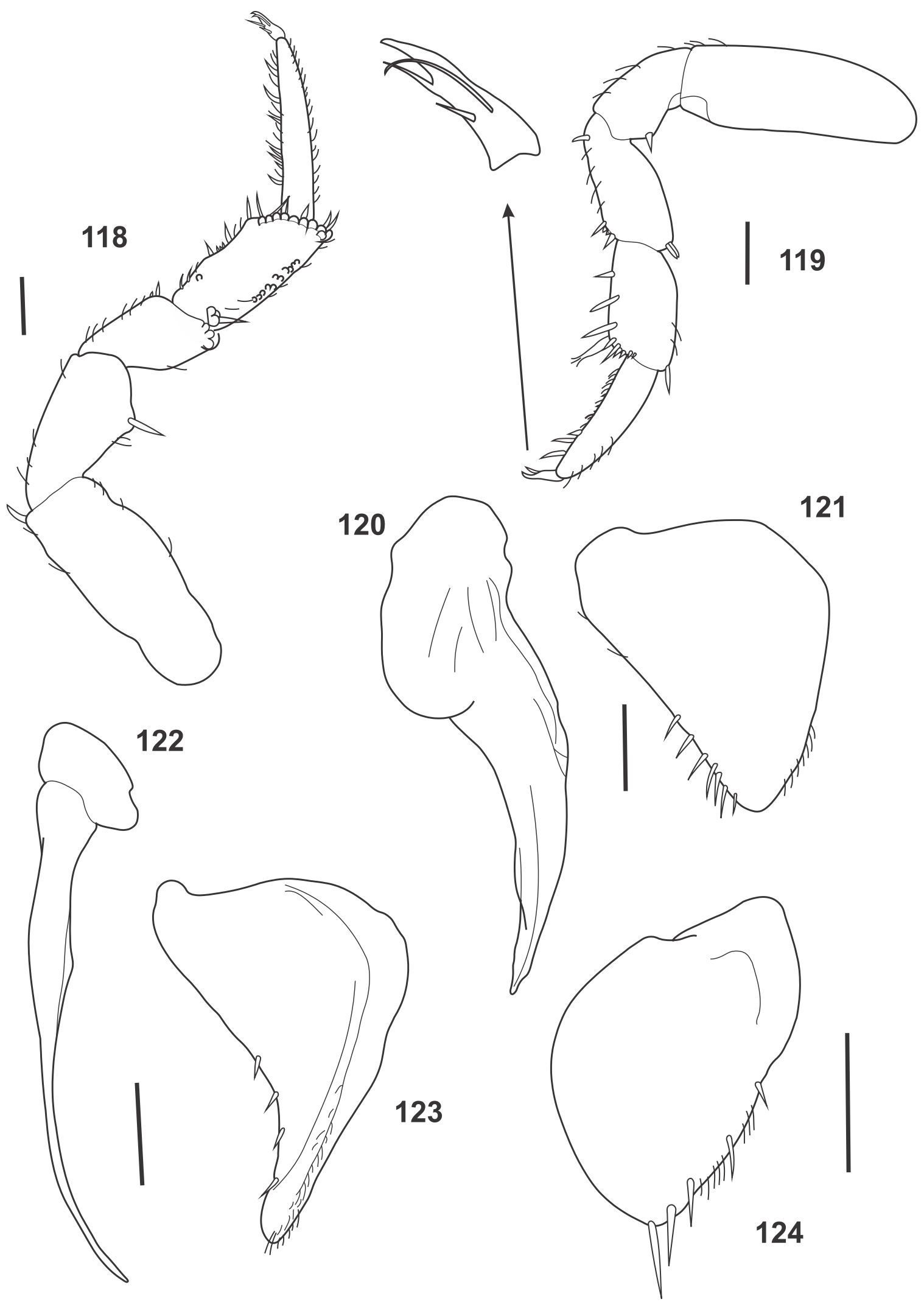

Figs. 118-124. Trichorhina tropidocerata sp. nov., male: 118, pereopod VII; 119, pereopod I; 120, exopod of pleopod I; 121, endopod of pleopod I; 122, endopod of pleopod II; 123, exopod of pleopod II; 124, exopod of pleopod V. Scale bars: $0.1 \mathrm{~mm}$. 
5. Left mandible with rods between molar and incisory processes; eye with five ommatidia; noduli laterales with featureless base . . . . . . . $\ldots \ldots \ldots \ldots \ldots \ldots$. . . . . . . . . . . . . . Left mandible without rods between molar and incisory processes; eye with one or two ommatidia; noduli laterales with base provided with two lateral processes . . . . . . . 6

6. Eye formed by two unequally sized ........ $\ldots \ldots \ldots \ldots \ldots$. . heterophthalma Eye formed by only one ommatidium . . . . . . $\ldots \ldots \ldots \ldots \ldots \ldots$. . . . . . . . . . . .

7. Second article of antennal peduncle ridged or crested . . . . . . . . . . . . . .8 Second article of antennal peduncle . . . . . . . . . . . . . . . . . . . . . . . .9

8. Eye formed by 15 ommatidia; second article of antennal peduncle with dorsal keel (Fig. 111) . . . . . . . . . . tropidocerata sp. nov. Eye formed by five ommatidia; second article of antennal peduncle with outer crenulate (Fig. 12) . . . . . . . . . . . biumbonata sp. nov.

9. Eye formed by a single very large ommatidium

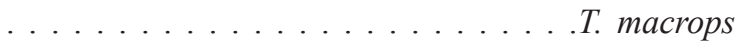
Eye formed by at least four ommatidia . . . 10 10. Eyes with four ommatidia . . . . . . . 11 Eyes with five to ten ommatidia . . . . . 13

11. Noduli laterales very close to the posterior border of pereonites I-VII (ratio b/c smaller than 0.1$) \ldots \ldots \ldots \ldots \ldots \ldots \ldots$. . . . . . . . . . . Noduli laterales located more far of the posterior border of pereonites I-VII (ratio b/c larger than 0.2, larger than 0.1 in P VII) (Fig. 6) . . . . . . . . . . sexdens sp. nov.

12. Telson clearly acute . . . . . . . T. acuta Telson subtriangular, with rounded apex..T. paraensis 13. Eyes formed by eight to ten ommatidia . . . . 14 Eyes formed by five to six ommatidia . . . . . 15 14. Noduli laterales with steep increase from P I to P II in $\mathrm{d} / \mathrm{c}$ (Fig. 2). . . . . . . T. crassisetae sp. nov. Noduli laterales without steep increase from $\mathrm{P}$ I to $\mathrm{P}$ II in $\mathrm{d} / \mathrm{c} \ldots . . . . . T$. amazonica 15. Exite of maxillula with $4+4$ (two cleft) teeth ............... argentina Exite of maxillula with $3+3-4$ (zero to two cleft) teeth . . . . . . . . . . . . . . 16

16. Pereon yellow to brown, pleon unpigmented; only six teeth at exite of maxillula, none cleft; molar process of left mandible with three penicils . . . . . . . . . . . bicolor
Body background of pereon and pleon uniform; seven teeth in exite of maxillula, one or two cleft; molar process of left mandible with only one penicil . . . . . . . . . 17

17. Body background brown with darker spots in head; eyes lighter; one cleft tooth in exite of maxillula (Fig. 50) . . . . . . . . . T. lenkoi sp. nov. Body pale yellow to unpigmented; eyes dark brown to black; two cleft teeth in exite of maxillula ......................18

18. Carpus of pereopod I of male without bristle field (Fig. 70) . . . . . . . T. myrmecophila sp. nov. Carpus of pereopod I of male with bristle field (Fig. 90) . . . . . . . . orensis sp. nov.

Acknowledgments. To Dr. Ana Maria S. P. Vanin (USP) for making material available for study; Dr. Eleonora Trajano (USP) for the material from cave of Mato Grosso do Sul and for providing encouragement along the years; Dr. Célia Maria de S. Sampaio (UECE) for laboratorial facilities; Claudia Melo (MZSP) for helping with the bibliography; Dr. Adriano B. Kury (MNRJ) for his great assistance in the early studies of this work and suggestions for the names of the species; Dr. Franco Ferrara (Centro di Studio per la Faunistica ed Ecologia Tropicali del C.N.R., Firenze) and the anonymous referees of Iheringia for the critical review of the manuscript; Catherine Ehret for the English review. Thanks are also due to Fundação Cearense de Apoio à Pesquisa (FUNCAP) and Conselho Nacional de Desenvolvimento Científico e Tecnológico (CNPq), for the financial support.

\section{REFERENCES}

ANDERSSON, A. 1960. South American terrestrial isopods in the collection of the Swedish State Museum of Natural History. Arkiv för Zoologi 12:537-570.

Araujo, P. B. \& Almerão, M. 2007. Nova espécie de Trichorhina (Isopoda, Oniscidea, Platyarthrydae) do Brasil. Iheringia, Série Zoologia 97(2):219-222.

AraúJo, P. B. \& Buckup, L. 1994. Nova espécie de Trichorhina BuddeLund, 1908 (Crustacea, Isopoda, Platyarthridae) do sul do Brasil. Iheringia, Série Zoologia 77:129-134.

1996. Novos registros e uma espécie nova de Trichorhina Budde-Lund, (Isopoda, Oniscidea, Platyarthridae) do sul do Brasil. Revista Brasileira de Zoologia 13:799-810.

BudDE-Lund, G. 1908. Isopoda von Madagaskar und Ostafrika mit Diagnosen verwandter Arten. In: Voeltzkow, A. ed. Reise in Ostafrika in den Jahren 1903-1905. Wissenschaftliche Ergebnisse, v.2. p. 265-308.

Leistikow, A. \& WÄGELE, J. 1999. Checklist of the terrestrial isopods of the new world (Crustacea, Isopoda, Oniscidea). Revista Brasileira de Zoologia 16:1-72.

Lemos de CASTRo, A. 1967. Isópodos terrestres da Amazônia brasileira (Isopoda, Oniscoidea). In: Lent, H. ed. Atas do Simpósio sôbre a Biota Amazônica. Rio de Janeiro, Conselho Nacional de Pesquisas, v.5. p. 311-336.

Schmalfuss, H. 2003. World catalog of terrestrial isopods (Isopoda: Oniscidea). Stuttgarter Beiträge zur Naturkunde, Serie A, 654:1-341.

Schultz, G. 1995. Terrestrial isopod crustaceans (Oniscidea) from Paraguay with definition of a new family. Revue Suisse de Zoologie 102:387-424.

SouZA-KuRY, L. 1993. Notes on Trichorhina I. Two new species from northeastern Brazil (Isopoda, Oniscidea, Platyarthridae). Revue Suisse de Zoologie 100:197-210. 
1997. Two new species of Trichorhina from Brazilian Amazonia (Isopoda, Oniscidea, Platyarthridae). Crustaceana 70:180-190.

Taiti, S. \& Ferrara, F. 1987. Contributions to the knowledge of the mountain fauna of Malawi. 6. Terrestrial isopods (Crustacea). Revue de Zoologie Africaine 101:69-102.

VANDEL, A. 1952. Etude des isopodes terrestres recoltes au Venezuela par le Dr. G. Marcuzzi. Memorie del Museo Civico di Storia Naurale di Verona 3: 59-203.
1959. Sur la présence du genre Trichorhina au Maroc et sur les affinités de ce genre (Crustacés, Isopodes terrestres). Bulletin du Muséum national d'Histoire Naturelle 31:100-104.

1962. Isopodes Terrestres (Deuxieme partie). In: Fédération Française des Sociétes de Sciences Naturelles. ed. Faune de France. Paris, P. Lechevalier. p.417-931.

VerhotFF, K. 1946. Über Land-Isopoden der Seychellen und aus Burma. Arkiv för Zoologi 37 A:1-18. 